Article

\title{
Developing a Proximal Active Canopy Sensor-based Precision Nitrogen Management Strategy for High-Yielding Rice
}

\author{
Junjun Lu ${ }^{1,2}$, Yuxin Miao ${ }^{1,3, *(\mathbb{D})}$, Wei Shi ${ }^{1}$, Jingxin Li ${ }^{1}$, Xiaoyi Hu ${ }^{1,4}$, Zhichao Chen ${ }^{2}$, \\ Xinbing Wang ${ }^{1}$ and Krzysztof Kusnierek ${ }^{5}$ (D) \\ 1 International Center for Agro-Informatics and Sustainable Development (ICASD), College of Resources and \\ Environmental Sciences, China Agricultural University, Beijing 100193, China; junjunlu@hpu.edu.cn (J.L.); \\ shiwei@alu.cau.edu.cn (W.S.); lijingxin@alu.cau.edu.cn (J.L.); hxy1223@alu.cau.edu.cn (X.H.); \\ xbwang2020@cau.edu (X.W.) \\ 2 Agro-Geoinformatics Research Center (ARC), School of Surveying and Land Information Engineering, \\ Henan Polytechnic University, Jiaozuo 454000, China; czc@hpu.edu.cn \\ 3 Precision Agriculture Center, Department of Soil, Water and Climate, University of Minnesota, St. Paul, \\ MN 55108, USA \\ 4 Beijing Agriculture Technology Extension Station, Beijing 100029, China \\ 5 Center for Precision Agriculture, Norwegian Institute of Bioeconomy Research (NIBIO), Nylinna 226, \\ 2849 Kapp, Norway; Krzysztof.Kusnierek@nibio.no \\ * Correspondence: ymiao@umn.edu
}

Received: 16 February 2020; Accepted: 29 April 2020; Published: 2 May 2020

\begin{abstract}
RapidSCAN is a portable active canopy sensor with red, red-edge, and near infrared spectral bands. The objective of this study is to develop and evaluate a RapidSCAN sensor-based precision nitrogen $(\mathrm{N})$ management $(\mathrm{PNM})$ strategy for high-yielding rice in Northeast China. Six rice N rate experiments were conducted from 2014 to 2016 at Jiansanjiang Experiment Station of China Agricultural University in Northeast China. The results indicated that the sensor performed well for estimating rice yield potential $\left(\mathrm{YP}_{0}\right)$ and yield response to additional $\mathrm{N}$ application $\left(\mathrm{RI}_{\text {Harvest }}\right)$ at the stem elongation stage using normalized difference vegetation index (NDVI) $\left(R^{2}=0.60-0.77\right.$ and relative error $(\mathrm{REr})=6.2-8.0 \%$ ) and at the heading stage using normalized difference red edge (NDRE) $\left(R^{2}=0.70-0.82\right.$ and $\left.\mathrm{REr}=7.3-8.7 \%\right)$. A new RapidSCAN sensor-based PNM strategy was developed that would make $\mathrm{N}$ recommendations at both stem elongation and heading growth stages, in contrast to previously developed strategy making $\mathrm{N}$ recommendation only at the stem elongation stage. This new PNM strategy could save $24 \% \mathrm{~N}$ fertilizers, and increase $\mathrm{N}$ use efficiencies by $29-35 \%$ as compared to Farmer N Management, without significantly affecting the rice grain yield and economic returns. Compared with regional optimum $\mathrm{N}$ management, the new PNM strategy increased $4 \%$ grain yield, 3-10\% N use efficiencies and $148 \$$ ha $^{-1}$ economic returns across years and varieties. It is concluded that the new RapidSCAN sensor-based PNM strategy with two in-season N recommendations using NDVI and NDRE is suitable for guiding in-season N management in high-yield rice management systems. Future studies are needed to evaluate this RapidSCAN sensor-based PNM strategy under diverse on-farm conditions, as well as to integrate it into high-yield rice management systems for food security and sustainable development.
\end{abstract}

Keywords: RapidSCAN sensor; nitrogen recommendation algorithm; in-season nitrogen management; nitrogen use efficiency; yield potential; yield responsiveness 


\section{Introduction}

As one of the major cereal crops in the world, more than half of the world's population takes rice (Oryza sativa L.) as the staple food [1]. The area under rice cultivation in Asia accounts for $90 \%$ of the world's total rice area [2]. At the same time, inappropriate nitrogen $(\mathrm{N})$ fertilizer application rates and timing result in low $\mathrm{N}$ use efficiency (NUE) in this area [3]. Northeast China is a major rice production region in China and the abovementioned management problems are common [4-6]. Facing these challenges, Chinese agricultural scientists have developed regional optimum N management (RONM) systems, aiming to obtain higher yields with less resources and $\mathrm{N}$ losses suitable for different regions $[4,6,7]$. The RONM system using fixed $\mathrm{N}$ rates and timing optimum for a region may not be optimal for a specific site, year, and variety in that region $[8,9]$. Precision N management (PNM) strategies consider both spatial and temporal variability in soil $\mathrm{N}$ supply and crop $\mathrm{N}$ demand. They have the potential to further improve NUE over the RONM strategy [8].

Active crop canopy sensors have been increasingly used to develop in-season site-specific $\mathrm{N}$ management strategies, allowing non-destructive real-time diagnosis of crop $\mathrm{N}$ status and $\mathrm{N}$ recommendations. They have their own light sources and are not affected by environmental light conditions [8]. The GreenSeeker active canopy sensor (Trimble Navigation Limited, Sunnyvale, CA, USA) is a commonly used sensor for guiding in-season $\mathrm{N}$ management [8]. It has red (R) and near-infrared (NIR) spectral wavebands and two default vegetation indices (VI): normalized difference vegetation index (NDVI) and ratio vegetation index (RVI) [8]. A GreenSeeker sensor-based PNM strategy has been previously developed to improve NUE while maintaining rice yield in Northeast China [10]. In this strategy, basal and tillering N rates were the same as RONM, while panicle fertilizer rates at the stem elongation stage were adjusted based on $\mathrm{N}$ fertilizer optimization algorithm using the GreenSeeker sensor [10]. The key components of this strategy include in-season estimation of yield potential without additional topdressing $\mathrm{N}$ application $\left(\mathrm{YP}_{0}\right)$ and $\mathrm{N}$ response index $\left(\mathrm{RI}_{\text {Harvest }}\right)$ [10-12]. The potential yield with sufficient topdressing $\mathrm{N}$ application $\left(\mathrm{YP}_{\mathrm{N}}\right)$ can be estimated by multiplying $\mathrm{YP}_{0}$ and $\mathrm{RI}_{\text {Harvest }}[11]$ and then the $\mathrm{N}$ topdressing requirement is estimated by dividing the yield increase $\left(\mathrm{YP}_{\mathrm{N}}-\mathrm{YP}_{0}\right)$ by the average NUE [10]. Because of the saturation problem of NDVI at moderate to high biomass conditions, the estimation of $\mathrm{YP}_{0}$ and $\mathrm{RI}_{\text {Harvest }}$ using GreenSeeker NDVI was not very satisfactory across all stages [10] or at later growth stages (e.g., the heading stage) [13]. A previous study using the Crop Circle ACS 470 sensor (Holland Scientific, Inc., Lincoln, NE, USA) indicated that red edge-based VIs had the potential to overcome the NDVI saturation problem and improve the estimation of $\mathrm{YP}_{0}$ and $\mathrm{RI}_{\text {Harvest }}$, especially at later rice growth stages [13].

The RapidSCAN CS-45 sensor (Holland Scientific Inc., Lincoln, Nebraska, USA) is a relatively new alternative active crop canopy sensor available in the market. It is a lightweight and convenient portable sensor with built-in global positioning system and red edge (RE) band in addition to red and near infrared bands. Another advantage of the RapidSCAN sensor is that the sensor data collection is not influenced by measurement height in the range of 0.3 to $3 \mathrm{~m}$ [14]. It provides NDVI and normalized difference red edge (NDRE) as two default VIs, in addition to the R, RE, and NIR waveband reflectance. Besides NDVI and NDRE, many different VIs can be calculated. This sensor was found to perform well for estimating rice $\mathrm{N}$ status indicators at different growth stages [14]. Zhang et al. [15] reported that NDRE had a better rice yield prediction accuracy than NDVI from stem elongation to booting stage using the RapidSCAN sensor. More studies are needed to develop RapidSCAN sensor-based PNM strategies for rice.

To ensure both food security and agricultural sustainable development, integrated precision rice management systems have been developed to increase rice yield and NUE simultaneously [16]. In such systems, in addition to $\mathrm{N}$ applications before transplanting, at the tillering and stem elongation stages, grain $\mathrm{N}$ fertilizer was also applied at the heading stage to better meet the $\mathrm{N}$ demand of high-yielding rice. The previously developed GreenSeeker-based PNM strategies did not perform well to guide grain $\mathrm{N}$ fertilizer application at the heading stage because of the NDVI saturation [13]. The RapidSCAN sensor has the potential to overcome the saturation problem of NDVI and research is needed to develop 
a RapidSCAN sensor-based PNM strategy for high-yielding rice management systems that will guide topdressing $\mathrm{N}$ applications at both stem elongation and heading stages.

Therefore, the objectives of this study are to (i) evaluate the potential of in-season estimation of the rice yield potential and the response to $\mathrm{N}$ application at different growth stages using the RapidSCAN CS-45 sensor, (ii) develop a RapidSCAN sensor-based PNM strategy for high-yielding rice, and (iii) evaluate the RapidSCAN sensor-based PNM strategy for different varieties, N status, and years in Northeast China.

\section{Materials and Methods}

\subsection{Study Site}

The study was conducted in Sanjiang Plain, Heilongjiang Province, Northeast China $\left(47.2^{\circ} \mathrm{N}\right.$, $\left.132.6^{\circ} \mathrm{E}\right)$. The main soil type in this area is Albic soil, classified as Mollic Planosols in the FAO-UNESCO system, and typical Argialbolls in the soil taxonomy [17]. The study site is located in a cool-temperate sub-humid continental monsoon climate zone. The temperature ranges from $-41^{\circ} \mathrm{C}$ in the winter to 38 ${ }^{\circ} \mathrm{C}$ in the summer, with a mean annual temperature of $1.9{ }^{\circ} \mathrm{C}$. About $72 \%$ of its annual precipitation (500-600 mm) occurs from June to September. The annual frost-free period is about 120-140 days long [16].

\subsection{Calibration and Validation Experiments}

Six plot experiments (Exp.) were conducted from 2014 to 2016 at Jiansanjiang Experiment Station of China Agricultural University, involving two different varieties, $\mathrm{N}$ rates and sensor-based $\mathrm{N}$ management strategies (Table 1). Each experiment had the same five $\mathrm{N}$ rates $(0,40,80,120$, and 160 $\mathrm{kg} \mathrm{N} \mathrm{ha}^{-1}$ ). In addition, the experiments in 2015-2016 consisted of a sensor-based PNM treatment using the RapidSCAN sensor. The $\mathrm{N}$ fertilizer was applied in five $\mathrm{N}$ rate treatments (except the control treatment without $\mathrm{N}$ application) as three splits: $40 \%$ as basal $\mathrm{N}$ before transplanting, $30 \%$ at tillering stage, and the remaining $30 \% \mathrm{~N}$ at the stem elongation stage. According to previous studies [6,9], the $\mathrm{N}$ rate treatment for $120 \mathrm{~kg} \mathrm{~N}^{-1}$ was used as RONM system in this region. The sensor-based PNM treatments were also based on the RONM system, with the same basal $\left(48 \mathrm{~kg} \mathrm{ha}^{-1}\right)$ and tillering $\left(36 \mathrm{~kg} \mathrm{ha}^{-1}\right) \mathrm{N}$ rates. The panicle and grain fertilizer rates were determined according to active canopy sensor-based $\mathrm{N}$ recommendation algorithm and applied at the stem elongation and heading stages, respectively.

Table 1. The details about the crop growth and crop sensing within the experiments performed in this study.

\begin{tabular}{|c|c|c|c|c|c|c|c|c|}
\hline \multirow{2}{*}{ Experiment } & \multirow{2}{*}{ Year } & \multirow{2}{*}{ Variety } & \multirow{2}{*}{ Transplanting Date } & \multirow{2}{*}{ Harvest Date } & \multicolumn{2}{|c|}{ Stem Elongation Stage } & \multicolumn{2}{|c|}{ Heading Stage } \\
\hline & & & & & Sensing Date & DAT & Sensing Date & DAT \\
\hline Exp. 1 & 2014 & \multirow{2}{*}{ Longjing 31} & 19 May & 29 September & 3 July & 45 & 26 July & 68 \\
\hline Exp. 3 & 2016 & & 19 May & 25 September & 5 July & 47 & 25 July & 67 \\
\hline Exp. 4 & 2014 & \multirow{2}{*}{ Longjing 21} & 19 May & 29 September & 7 July & 49 & 26 July & 68 \\
\hline Exp. 6 & 2016 & & 19 May & 25 September & 5 July & 47 & 25 July & 67 \\
\hline
\end{tabular}

Note: DAT: the number of days from transplanting to sensing.

Exp. 1 to 3 used Longjing 31, which is an 11-leaf variety requiring about 130 days to reach maturity. Exp. 4 to 6 used Longing 21, which is a 12-leaf variety that needs about 133 days to maturity. All plot experiments were replicated three times in a randomized complete block design. The $\mathrm{N}$ source was granular urea. To evaluate the potential of the crop canopy sensors to estimate rice $\mathrm{YP}_{0}$ and $\mathrm{RI}_{\text {Harvest }}$ at

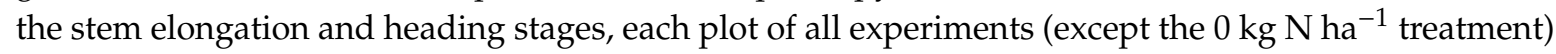


was divided into two parts: $4.5 \times 9 \mathrm{~m}$ as the main plot and $2.5 \times 9 \mathrm{~m}$ as the subplot without receiving the third $\mathrm{N}$ application. For all the treatments, $50 \mathrm{~kg} \mathrm{P}_{2} \mathrm{O}_{5} \mathrm{ha}^{-1}$ in the form of $\mathrm{Ca}\left(\mathrm{H}_{2} \mathrm{PO}_{4}\right)_{2}$ was applied before transplanting and $105 \mathrm{~kg} \mathrm{~K}_{2} \mathrm{O} \mathrm{ha}^{-1}$ in the form of $\mathrm{KCl}$ was applied as two splits: $50 \%$ before transplanting and 50\% at the stem elongation stage. Rice seedlings were prepared in a greenhouse and transplanted into the experimental fields in mid-May. The field and crop management in these experiments followed the regional recommendations.

\subsection{Proximal Sensing Data Collection}

The RapidSCAN CS-45 sensor was used to collect reflectance data in this study. The sensor with modulated light emitting diodes irradiates the crop canopy and determines a portion of the radiation reflected from the crop canopy, without being affected by ambient illumination. The internal polychromatic light source includes three spectral bands centered at R (670 nm), RE (730 nm), and NIR $(780 \mathrm{~nm})$ wavelengths. According to the manufacturer, the sensor has the unique feature of Pseudo Solar Reflectance measurements that are independent of height in the range of $0.3 \mathrm{~m}$ to $3 \mathrm{~m}$. Considering the potential influence of viewing angle and measurement area on sensor readings, the sensor footprint was parallel to the plant rows with the beam of light being perpendicular to rice canopy about $0.7-0.9$ $\mathrm{m}$ above the canopy. The sensor was carried at a consistent speed to collect sensor readings from four different rows ( $3 \mathrm{~m}$ per row) in the middle of each plot. The reflectance values were then averaged to represent the reflectance for each plot.

Following the methodology established in the previous study on the RapidSCAN sensor [14], fifty-one VIs were evaluated in this study for estimating $\mathrm{YP}_{0}$ and $\mathrm{RI}_{\text {Harvest }}$ and the best performing VIs for calibration and validation are listed in Table 2. NDVI and NDRE were provided as two default indices for this sensor (see Table 2). Reflectance data were collected at stem elongation and heading stages, which were the key stages for panicle and grain fertilizer applications.

Table 2. NDVI, NDRE, and the best performing vegetation indices for calibration and validation from RapidSCAN used in this study.

\begin{tabular}{|c|c|c|}
\hline Index & Formula & Reference \\
\hline Normalized difference red edge (NDRE) & $(\mathrm{NIR}-\mathrm{RE}) /(\mathrm{NIR}+\mathrm{RE})$ & Barnes et al. [19] \\
\hline Modified soil-adjusted vegetation index (MSAVI) & $(2 \times \mathrm{NIR}+1)-\sqrt{(2 \times \mathrm{NIR}+1)^{2}-8(\mathrm{NIR}-\mathrm{R})} / / 2$ & Qi et al. [21] \\
\hline Modified simple ratio (MSR) & $(\mathrm{NIR} / \mathrm{R}-1) / \sqrt{\mathrm{NIR} / \mathrm{R}+1}$ & Chen [22] \\
\hline NDVI*RVI & $\left(\mathrm{NIR}^{2}-\mathrm{R}\right) /\left(\mathrm{NIR}+\mathrm{R}^{2}\right)$ & Gong et al. [25] \\
\hline Red edge wide dynamic range vegetation index (REWDRVI) & $(0.12 \mathrm{INIR}-\mathrm{RE}) /(0.12 \mathrm{RNIR}+\mathrm{RE})$ & Cao et al. [26] \\
\hline Red edge optimal soil adjusted vegetation index (REOSAVI) & $(1+0.16)(\mathrm{NIR}-\mathrm{RE}) /(\mathrm{NIR}+\mathrm{RE}+0.16)$ & Cao et al. [26] \\
\hline Modified red edge soil adjusted vegetation index (MRESAVI) & $(2 \times \mathrm{NIR}+1)-\sqrt{(2 \times \mathrm{NIR}+1)^{2}-8(\mathrm{NIR}-\mathrm{RE})} / / 2$ & Cao et al. [26] \\
\hline Optimized red edge vegetation index $\left(\mathrm{REVI}_{\mathrm{opt}}\right)$ & $100 \times(\ln N I R-\ln R E)$ & Jasper et al. [27] \\
\hline
\end{tabular}

\subsection{Plant Sampling and Measurements}

At the stem elongation, heading, and maturity stages, 3 hills with tillers representative of each plot were randomly selected for assessing the aboveground biomass. After cleaning with water, all roots were removed. The plant samples were then oven dried for $30 \mathrm{~min}$ at $105^{\circ} \mathrm{C}$ and then at $70{ }^{\circ} \mathrm{C}$ until constant weight, and weighed to determine their biomass. They were later ground to pass a $0.5 \mathrm{~mm}$ sieve. Plant N concentration was determined using the Kjeldahl-N method.

Rice was harvested at the end of September or early October. Grain yield was determined by hand harvesting three $1 \mathrm{~m}^{2}$ areas in each plot where spectral reflectance data were collected. Grains were separated from straw using a small grain thresher and then weighed. Grain moisture was determined immediately after weighing. The rice grain weight was adjusted to a moisture content of $140 \mathrm{~g} \mathrm{~kg}^{-1}$. 
Agronomic efficiency of $\mathrm{N}\left(\mathrm{AE}_{\mathrm{N}}\right)$ and partial factor productivity of $\mathrm{N}\left(\mathrm{PFP}_{\mathrm{N}}\right)$ were calculated using the following equations:

$$
\begin{gathered}
\mathrm{AE}_{\mathrm{N}}\left(\mathrm{kg} \mathrm{kg}^{-1}\right)=\frac{\text { Grain yield }- \text { Grain yield at control }}{\mathrm{N} \text { rate }} \times 100 \\
\operatorname{PFP}_{\mathrm{N}}\left(\mathrm{kg} \mathrm{kg}^{-1}\right)=\frac{\text { Grain yield }}{\mathrm{N} \text { rate }}
\end{gathered}
$$

\subsection{Development and Evaluation of RapidSCAN-Based Precision Nitrogen Management Strategies}

Based on Yao et al. [10], the RapidSCAN-based PNM strategy in this study was developed by first establishing the models to estimate $\mathrm{YP}_{0}$ and $\mathrm{RI}_{\text {Harvest }}$ using in-season estimate of yield (INSEY) and in-season N response index based on VI (RI-VI), respectively. INSEY can be regarded as an estimate of average daily biomass production from the time of transplanting to the day of sensing [11]. It was calculated as NDVI divided by the number of growing degree days $>0$ [10]. In this study, however, the number of days from transplanting to sensing was used instead of growing degree days to calculate INSEY, similarly to the method of Cao et al. [13]. With respect to their study, the selected RapidSCAN VIs were used here to replace the GreenSeeker NDVI or RVI. $\mathrm{RI}_{\text {Harvest }}$ indicates the actual crop yield response to additional $\mathrm{N}$ within a given year $[28,29]$ and was calculated as follows [13]:

$$
\mathrm{RI}_{\text {Harvest }}=\frac{\text { Yield_N } \mathrm{N}_{\text {rich }}}{\text { Yield_CK }}
$$

where Yield_ $\mathrm{N}_{\text {rich }}$ is the average yield of plots receiving sufficient $\mathrm{N}$ application (the $160 \mathrm{~kg} \mathrm{~N} \mathrm{ha}^{-1}$ treatment in this study), and Yield_CK is the average yield of plot without receiving the third N application at the stem elongation stage or the fourth $\mathrm{N}$ application at the heading stage.

RI-VI was calculated in the same way as $\mathrm{RI}_{\text {Harvest }}$, with the exception that VIs derived from RapidSCAN sensor were used instead of yield. $\mathrm{YP}_{\mathrm{N}}$ was calculated by multiplying $\mathrm{YP}_{0}$ and $\mathrm{RI}_{\text {Harvest }}$. Finally, the $\mathrm{N}$ topdressing requirement is estimated by dividing the yield gap $\left(\mathrm{YP}_{\mathrm{N}}-\mathrm{YP}_{0}\right)$ by the average $\mathrm{AE}$ of topdressing $\mathrm{N}$ ( $\mathrm{AE}_{\text {topdressing }}$ [10]. The $\mathrm{AE}_{\text {topdressing }}$ should be higher than the one for the whole season, and will be predicted during the growing season using the predicted $\mathrm{RI}_{\text {Harvest }}[30]$.

To ensure sufficient $\mathrm{N}$ supply for grain filling and higher NUE in high-yield rice management systems, a strategy for in-season site-specific $\mathrm{N}$ management of rice using RapidSCAN at stem elongation and heading stages was developed in this study (Figure 1). First, the topdressing $\mathrm{N}$ application rate $\left(\mathrm{N}_{\text {rate }}\right)$ at stem elongation stage was determined as mentioned above, and then this rate was split in two doses, $2 / 3$ as panicle fertilizer at stem elongation stage (SE_N $\mathrm{N}_{\text {rate }}$ ) and 1/3 for grain fertilizer at the heading stage. Second, the RapidSCAN sensor was used to estimate the potential yield with added $\mathrm{N}$ application at the heading stage $\left(\mathrm{HD}_{-} \mathrm{YP}_{\mathrm{N}}\right)$. The difference between estimated $\mathrm{YP}_{\mathrm{N}}$ at stem elongation and heading stages $\left(\mathrm{HD}_{-} \mathrm{YP}_{\mathrm{N}}-\mathrm{SE}_{-} \mathrm{YP}_{\mathrm{N}}\right)$ was used to adjust the remaining $1 / 3$ $\mathrm{N}_{\text {rate }}$ to match the crop $\mathrm{N}$ demand at the heading stage. Therefore, the recommended $\mathrm{N}$ topdressing application rate at the heading stage (HD_N $\mathrm{N}_{\text {rate }}$ ) can be determined as follows (Figure 1):

$$
\mathrm{HD} \_\mathrm{N}_{\text {rate }}=\frac{\mathrm{HD}_{-} \mathrm{YP}_{\mathrm{N}}-\mathrm{SE} \_\mathrm{YP}_{\mathrm{N}}}{\mathrm{AE}_{\text {topdressing }}}+\frac{1}{3} \mathrm{~N}_{\text {rate }}
$$

where $\mathrm{HD} \_\mathrm{N}_{\text {rate }}$ is the topdressing $\mathrm{N}$ application rate at heading stage, $\mathrm{HD}_{-} \mathrm{YP}_{\mathrm{N}}$ is the predicted yield potential with topdressing $\mathrm{N}$ application at heading stage, $\mathrm{SE}_{-} \mathrm{YP}_{\mathrm{N}}$ is the predicted yield potential with topdressing $\mathrm{N}$ application at the stem elongation stage, and $\mathrm{AE}_{\text {topdressing }}$ is the topdressing $\mathrm{N}$ agronomic efficiency. 


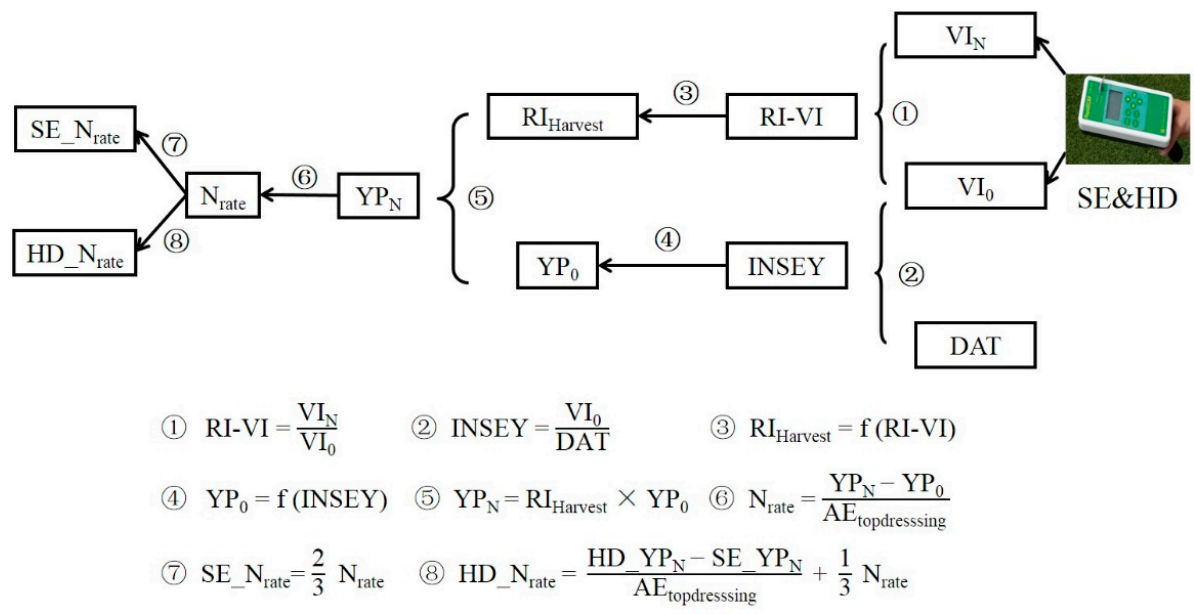

Figure 1. RapidSCAN sensor-based in-season $\mathrm{N}$ recommendation algorithm developed for determining topdressing $\mathrm{N}$ rates at stem elongation stage and heading stage of high-yielding rice in this study. $\mathrm{VI}_{\mathrm{N}}$ : vegetation index at plots with sufficient $\mathrm{N}$ fertilization plots; $\mathrm{VI}_{0}$ : vegetation index at plots without additional $\mathrm{N}$ topdressing application; RI-VI: in-season $\mathrm{N}$ response index based on vegetation index; $\mathrm{RI}_{\text {Harvest }}$ : $\mathrm{N}$ response index based on yield; DAT: the number of days from planting to the date of sensing; INSEY: in-season estimate of yield; $\mathrm{YP}_{0}$ : the potential yield without additional topdressing $\mathrm{N}$ application; $\mathrm{N}_{\text {rate }}$ : recommended topdressing $\mathrm{N}$ application rate at stem elongation

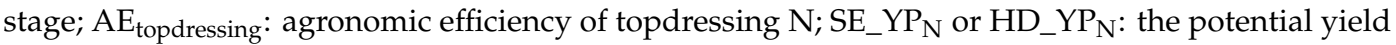
with added topdressing $\mathrm{N}$ application at the stem elongation stage or heading stage, respectively; SE_N $\mathrm{N}_{\text {rate }}$ or HD_N $\mathrm{N}_{\text {rate }}$ : recommended topdressing $\mathrm{N}$ application rate at the stem elongation stage or heading stage, respectively.

In addition, two restrictions were applied after considering the rice production situation in Northeast China:

$$
\begin{gathered}
\mathrm{YP}_{\mathrm{N}} \leq \mathrm{YP}_{\max }\left(12 \mathrm{t} \mathrm{ha}^{-1}\right) \\
\mathrm{N}_{\text {min }}\left(0 \mathrm{~kg} \mathrm{ha}^{-1}\right) \leq \mathrm{N}_{\text {rate }} \leq \mathrm{N}_{\max }\left(48 \mathrm{~kg} \mathrm{ha}^{-1}\right)
\end{gathered}
$$

where $\mathrm{YP}_{\max }$ is the maximum obtainable yield, $\mathrm{N}_{\min }$ and $\mathrm{N}_{\max }$ are the minimum and maximum topdressing $\mathrm{N}$ rates.

According to the definition and the methods of Raun et al. [11] and [12], the $\mathrm{YP}_{\max }$ in the study region was set to $12 \mathrm{tha}^{-1}$ based on previous studies and farmer survey data in this region $[10,13,16,31]$. The topdressing $\mathrm{N}$ application rates at the stem elongation stage was set to 0 to $48 \mathrm{~kg} \mathrm{ha}^{-1}$ based on farmer surveys and previous studies in this region [10,16,31].

In order to determine whether the restrictions applied to the rice PNM strategies were suitable, three $\mathrm{N}$ rate treatments $\left(80,120\right.$, and $\left.160 \mathrm{~kg} \mathrm{ha}^{-1}\right)$ from Exp. 1-6 were chosen to represent three rice $\mathrm{N}$ status before topdressing (deficient, optimal, and surplus, respectively). They were used to evaluate the RONM and the developed PNM strategies by calculating the differences between economically optimum $\mathrm{N}$ rate (EONR) and $\mathrm{N}$ rates recommended by RONM or PNM strategies. In order to evaluate the potential of the developed PNM strategy, the RapidSCAN-based PNM treatment in Exp. 2-3 and 5-6 was compared for yield, $\mathrm{N}$ rate, and NUE with the control treatment $\left(0 \mathrm{~kg} \mathrm{~N} \mathrm{ha}^{-1}\right)$, the $160 \mathrm{~kg} \mathrm{~N}$ $\mathrm{ha}^{-1}$ treatment reflecting the farmer $\mathrm{N}$ management (FNM) and the $120 \mathrm{~kg} \mathrm{~N} \mathrm{ha}^{-1}$ identical with the RONM. For the RapidSCAN sensor-based PNM treatment, the topdressing $\mathrm{N}$ rate was estimated based on the PNM strategy developed in this study using NDVI at the stem elongation stage and NDRE at the heading stage (Exp. 2 and 5 using data up to 2015; Exp. 3 and 6 using data up to 2016).

Economic return to $\mathrm{N}\left(\mathrm{E}, \$ \mathrm{ha}^{-1}\right)$ was used to evaluate the profitability of different $\mathrm{N}$ management systems, and was calculated as follows:

$$
\mathrm{E}=\left(\mathrm{Y}_{\mathrm{N}}-\mathrm{Y}_{0}\right) \times \mathrm{P}_{\mathrm{Y}}-\mathrm{N}_{\text {total }} \times \mathrm{P}_{\mathrm{N}}
$$


where $Y_{N}\left(\mathrm{~kg} \mathrm{ha}^{-1}\right)$ is the rice grain yield with $\mathrm{N}$ application, $\mathrm{Y}_{0}\left(\mathrm{~kg} \mathrm{ha}^{-1}\right)$ is the rice grain yield of the check treatment without any $\mathrm{N}$ application, $\mathrm{P}_{\mathrm{Y}}$ is rice grain price $\left(0.44 \$ \mathrm{~kg}^{-1}\right) . \mathrm{N}_{\text {total }}$ is the total $\mathrm{N}$ fertilizer application rate $\left(\mathrm{kg} \mathrm{ha}^{-1}\right)$. $\mathrm{P}_{\mathrm{N}}$ is the $\mathrm{N}$ fertilizer price $\left(0.54 \$ \mathrm{~kg}^{-1}\right)$.

\subsection{Statistical Analysis}

Data collected from the three-year experiments were pooled together and then randomly divided into calibration dataset ( $67 \%$ of the observations) and validation dataset ( $33 \%$ of the observations) for the estimation of $\mathrm{YP}_{0}$ and $\mathrm{RI}_{\text {Harvest }}$ using RapidSCAN sensor. The coefficients of determination $\left(R^{2}\right)$ for the relationships between VIs and agronomic parameters were calculated using SPSS 18.0 (SPSS Inc., Chicago, Illinois, USA), and the models with the highest $\mathrm{R}^{2}$ were selected. In addition to $\mathrm{R}^{2}$, the performance of the models for predicting $\mathrm{YP}_{0}$ and $\mathrm{RI}_{\text {Harvest }}$ was also evaluated using the root mean square error (RMSE) and relative error (REr). Analysis of variance were conducted using the SAS software package Version 9.0 (SAS Institute Inc., Cary, NC, USA). The means for treatments were compared with least significant difference (LSD) test at the 0.05 probability level (at $p<0.05$ ).

\section{Results}

\subsection{Changes in NDVI vs. NDRE among Different N Rates, Varieties, Stages, and Years}

Rice grain yield was significantly affected by the factors of $\mathrm{N}$ rates, varieties, and years, and RapidSCAN-based NDVI and NDRE also showed similar results (Table 3). Except for the variation of year, NDVI was significantly affected across different $\mathrm{N}$ rates, varieties, and growth stages. NDRE was significantly affected by these factors, except for variety. The changes in NDVI vs. NDRE were also shown in Figure 2. $\mathrm{YP}_{0}, \mathrm{NDVI}$, and NDRE all increased with $\mathrm{N}$ rates (Figure 3). The average NDVI showed significant difference between Longjing 31 (0.68) and Longjing 21 (0.72) across years, growth stages, and $\mathrm{N}$ levels.
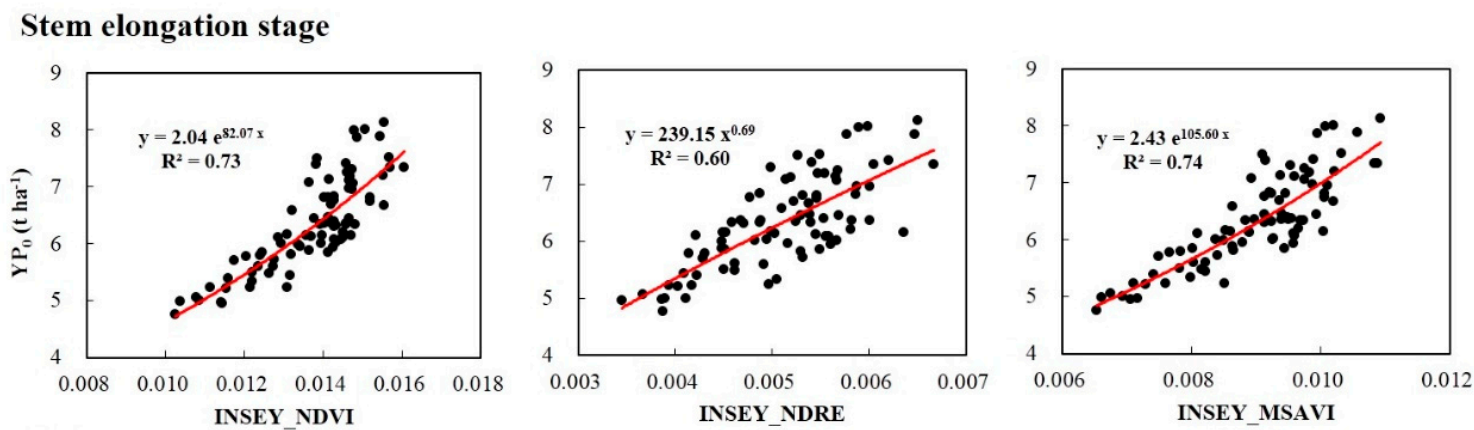

Heading stage
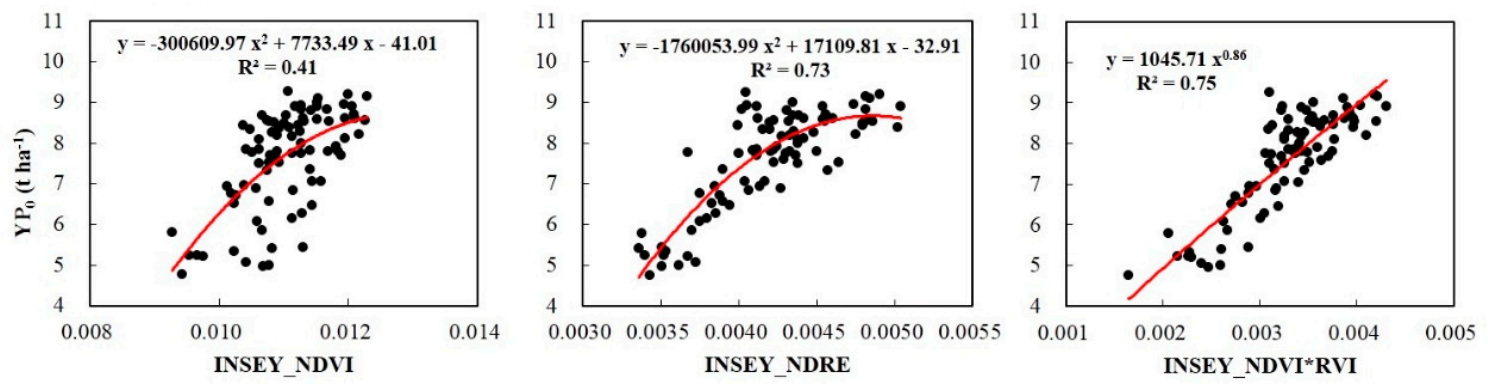

Figure 2. The relationships between yield without additional topdressing $\mathrm{N}$ application $\left(\mathrm{YP}_{0}\right)$ and in-season estimate of yield (INSEY) calculated with NDVI, NDRE, MSAVI, and NDVI*RVI across all varieties at stem elongation stage and heading stage. 
Table 3. Significance of mean squares in the analysis of yield without additional topdressing $\mathrm{N}$ application $\left(\mathrm{YP}_{0}\right)$, RapidSCAN NDVI, and NDRE under five $\mathrm{N}$ rates $\left(0,40,80,120,180 \mathrm{~kg} \mathrm{ha}^{-1}\right)$ combined at two stages (stem elongation and heading stage), across three years (2014-2016) for two varieties (Longjing 31 and Longjing 21).

\begin{tabular}{ccccc}
\hline \multirow{2}{*}{ Source of Variation } & \multirow{2}{*}{ Degree of Freedom } & \multicolumn{3}{c}{ Significance of Mean Square } \\
\cline { 3 - 5 } & & NDVI & NDRE & YP $_{\mathbf{0}}$ \\
\hline N level & 4 & $* * *$ & $* * *$ & $* * *$ \\
Variety & 1 & $* * *$ & ns & $* * *$ \\
Stage & 1 & ns & $* * *$ & $* * *$ \\
Year & 2 & & $* * *$
\end{tabular}

Note: ${ }^{* * *}$, and ${ }^{* * *}$ indicate significance at $0.05,0.01$, and 0.001 probability levels, respectively. $\mathrm{ns}=$ non-significant.
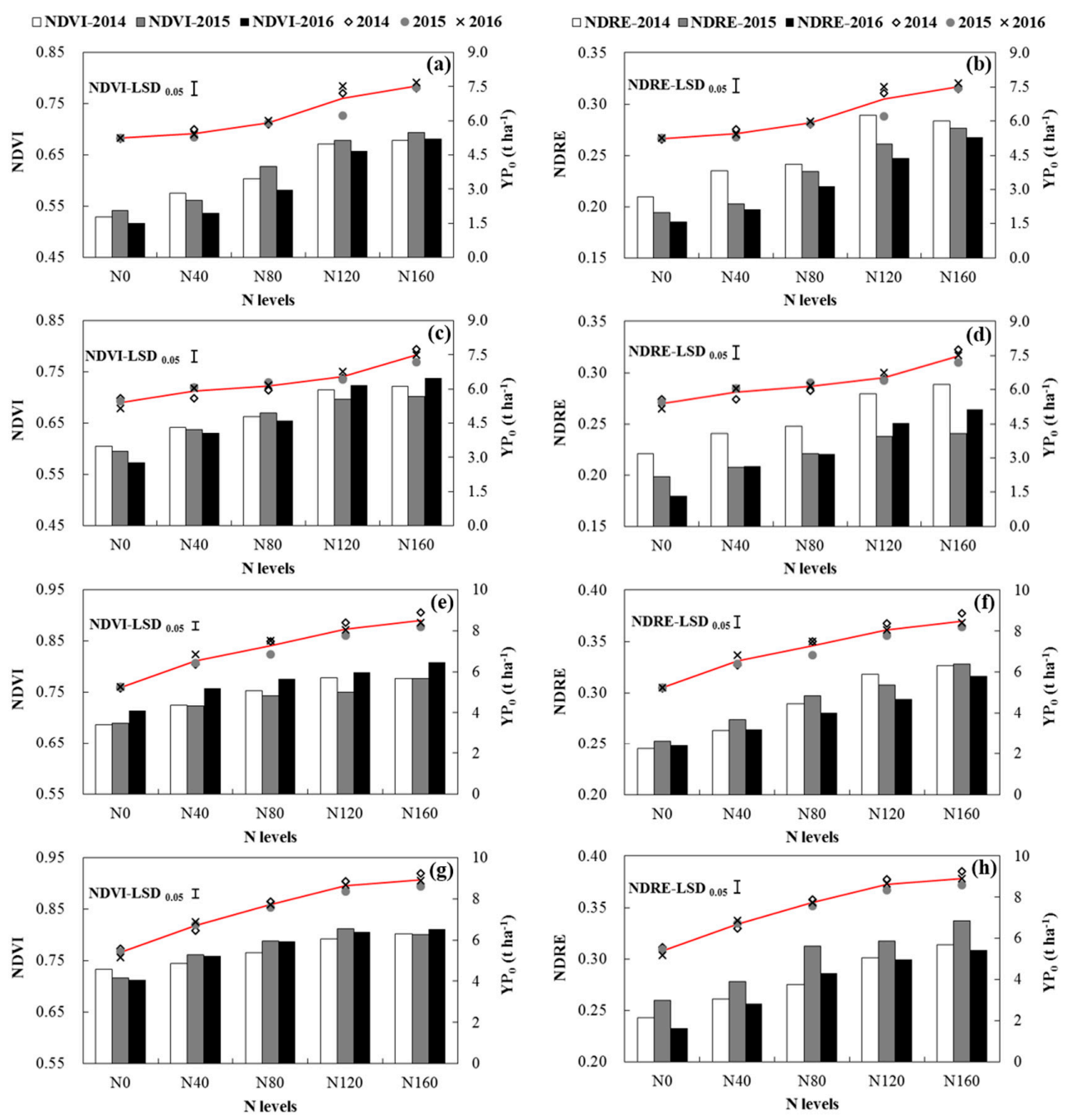

Figure 3. Rice yield without additional topdressing $\mathrm{N}$ application $\left(\mathrm{YP}_{0}\right)$ or NDVI (a; $\left.\mathbf{c} ; \mathbf{e} ; \mathbf{g}\right)$ and $\mathrm{YP}_{0}$ or NDRE $(\mathbf{b} ; \mathbf{d} ; \mathbf{f} ; \mathbf{h})$ obtained by RapidSCAN at the stem elongation $(\mathbf{a}-\mathbf{d})$ and heading $(\mathbf{e}-\mathbf{h})$ stages as affected by different $\mathrm{N}$ rates for Longjing 31 (a; b; e; f) and Longjing 21 (c; d; $\mathbf{g}$; h) in 2014-2016, respectively. Different color bars represent the value of NDVI or NDRE in different years. Different dots represent $\mathrm{YP}_{0}$ in different years. The red curves were the curves of rice yield potential without additional topdressing $\mathrm{N}$ application $\left(\mathrm{YP}_{0}\right)$. Vertical bars represent the LSD value $(p=0.05)$ among different $\mathrm{N}$ levels. 


\subsection{Yield Without Additional Topdressing $N$ Application}

The performance of the INSEY calculated with NDVI, NDRE, and best performing VIs to estimate rice $\mathrm{YP}_{0}$ varied with different growth stages across $\mathrm{N}$ rate treatments, sites, and years (Table 4 and Figure 2). At the stem elongation growth stage, two varieties performed similarly. INSEY-NDVI explained $72-76 \%$ of $\mathrm{YP}_{0}$ variability, which was better than INSEY-NDRE (60-66\%). The INSEY calculated with best performing VIs (nonlinear index (NLI) (INSEY_NLI), modified simple ratio (MSR) (INSEY_MSR), and modified soil-adjusted vegetation index (MSAVI) (INSEY_MSAVI)) performed similarly $\left(R^{2}=0.74-0.78\right)$ to INSEY_NDVI.

Table 4. Calibration and validation results for predicting yield without additional topdressing $\mathrm{N}$ application $\left(\mathrm{YP}_{0}\right)$ using the in-season estimate of yield (INSEY) calculated with the RapidSCAN's default indices (NDVI and NDRE) and the best performing vegetation indices for two varieties at the stem elongation (SE) and heading (HD) stages in 2014-2016.

\begin{tabular}{|c|c|c|c|c|c|c|c|}
\hline \multirow{2}{*}{ Variety } & \multirow{2}{*}{ Stage } & \multicolumn{3}{|c|}{ Calibration Results } & \multicolumn{3}{|c|}{ Validation Results } \\
\hline & & Index & Model & $\mathbf{R}^{2}$ & $\mathbf{R}^{2}$ & RMSE & REr \\
\hline \multirow{6}{*}{ Longjing 31} & \multirow{3}{*}{ SE } & INSEY_NDVI & $\mathrm{E}$ & 0.76 & 0.70 & 0.49 & 7.7 \\
\hline & & INSEY_NDRE & $\mathrm{P}$ & 0.66 & 0.62 & 0.55 & 8.5 \\
\hline & & INSEY_NLI & E & 0.78 & 0.70 & 0.49 & 7.6 \\
\hline & \multirow{3}{*}{ HD } & INSEY_NDVI & Q & 0.59 & 0.54 & 0.74 & 9.9 \\
\hline & & INSEY_NDRE & Q & 0.89 & 0.76 & 0.54 & 7.3 \\
\hline & & INSEY_REOSAVI & Q & 0.89 & 0.76 & 0.55 & 7.3 \\
\hline \multirow{6}{*}{ Longjing 21} & \multirow{3}{*}{ SE } & INSEY_NDVI & $\mathrm{E}$ & 0.72 & 0.66 & 0.39 & 6.3 \\
\hline & & INSEY_NDRE & $\mathrm{P}$ & 0.62 & 0.34 & 0.54 & 8.7 \\
\hline & & INSEY__MSR & E & 0.74 & 0.63 & 0.41 & 6.5 \\
\hline & \multirow{3}{*}{ HD } & INSEY_NDVI & Q & 0.28 & 0.64 & 0.93 & 12.1 \\
\hline & & INSEY_NDRE & $\hat{\mathrm{Q}}$ & 0.77 & 0.75 & 0.66 & 8.5 \\
\hline & & INSEY_MRESAVI & Q & 0.78 & 0.72 & 0.69 & 9.0 \\
\hline \multirow{6}{*}{ Across varieties } & \multirow{3}{*}{ SE } & INSEY_NDVI & $\mathrm{E}$ & 0.73 & 0.66 & 0.47 & 7.4 \\
\hline & & INSEY_NDRE & $\mathrm{P}$ & 0.60 & 0.49 & 0.56 & 8.8 \\
\hline & & INSEY_MSAVI & $\mathrm{E}$ & 0.74 & 0.65 & 0.47 & 7.4 \\
\hline & \multirow{3}{*}{ HD } & INSEY_NDVI & Q & 0.41 & 0.59 & 0.81 & 10.7 \\
\hline & & INSEY_NDRE & $\hat{\mathrm{Q}}$ & 0.73 & 0.70 & 0.65 & 8.6 \\
\hline & & INSEY_NDVI*RVI & $\widetilde{\mathrm{P}}$ & 0.75 & 0.70 & 0.66 & 8.7 \\
\hline
\end{tabular}

Note: Q, E, and P: stand for quadratic, exponential, and power models. RMSE: root mean square error. REr: relative error $(\%)$.

At the heading stage, however, INSEY_NDVI did not perform very well, explaining only 28-59\% of the $\mathrm{YP}_{0}$ variability. Moreover, INSEY_NDRE performed consistently better than INSEY_NDVI, explaining $73-89 \%$ of the $\mathrm{YP}_{0}$ variability (Table 4). The INSEY calculated with red edge optimal soil adjusted vegetation index (REOSAVI) (INSEY_REOSAVI), modified red edge soil adjusted vegetation index (MRESAVI) (INSEY_MRESAVI), and NDVI*RVI (INSEY_NDVI*RVI), did not perform significantly better than INSEY_NDRE (Table 4). Furthermore, the $\mathrm{YP}_{0}$ was better estimated using INSEY for Longjing 31 than for Longjing 21.

The validation results were similar to the calibration results (Table 4). At the stem elongation stage, the INSEY_NDVI and INSEY calculated with best performing VI had similar performance for predicting $\mathrm{YP}_{0}$, with $\mathrm{R}^{2}$, RMSE, and REr of $0.65-0.66,0.47$, and $7.4 \%$ across both varieties. At the heading stage, INSEY_NDRE and INSEY calculated with best performing VI performed similarly for predicting $\mathrm{YP}_{0}$, with $\mathrm{R}^{2}$, RMSE, and REr of $0.70,0.65-0.66$, and 8.6-8.7\%, respectively. 


\subsection{The Responsiveness to Topdressing N Application}

The performance of the RI_VI calculated with NDVI (RI_NDVI), NDRE (RI_NDRE), and best performing VIs to estimate rice $\mathrm{RI}_{\text {Harvest }}$ varied with growth stages across $\mathrm{N}$ rate treatments, sites, and years (Table 5 and Figure 4). At the stem elongation stage, RI_NDRE and RI calculated with best performing VIs (optimal vegetation index $\left(\mathrm{VI}_{\mathrm{opt}}\right)$, red edge wide dynamic range vegetation index (REWDRVI) and RVI) did not perform significantly better than RI_NDVI $\left(R^{2}=0.67-0.78\right)$. The $\mathrm{RI}_{\text {Harvest }}$ was estimated better for Longjing $31\left(\mathrm{R}^{2}=0.71-0.79\right)$ than for Longjing $21\left(\mathrm{R}^{2}=0.68-0.71\right)$ or across varieties $\left(R^{2}=0.64-0.68\right)$. The validation results showed similar pattern to the calibration results (Table 5). The prediction of $\mathrm{RI}_{\text {Harvest }}$ for Longjing $31\left(\mathrm{R}^{2}=0.72-0.78, \mathrm{RMSE}=0.08-0.09\right.$ and $\mathrm{REr}=6.1-6.8)$ was better than for Longjing $21\left(\mathrm{R}^{2}=0.60-0.67\right.$, RMSE $=0.10-0.11$ and $\left.\mathrm{REr}=7.0-7.4\right)$ or across varieties $\left(\mathrm{R}^{2}=0.61-0.63\right.$, $\mathrm{RMSE}=0.11$ and $\left.\mathrm{REr}=7.8-8.0\right)$.

Table 5. Calibration and validation results for the response index calculated with yield $\left(\mathrm{RI}_{\text {Harvest }}\right)$ predicted by response index calculated with NDVI, NDRE, and the best performing vegetation indices for two varieties at stem elongation stage (SE) and heading stage (HD) in 2014-2016.

\begin{tabular}{|c|c|c|c|c|c|c|c|}
\hline \multirow{2}{*}{ Variety } & \multirow{2}{*}{ Stage } & \multicolumn{3}{|c|}{ Calibration Results } & \multicolumn{3}{|c|}{ Validation Results } \\
\hline & & Index & Model & $\mathbf{R}^{2}$ & $\mathbf{R}^{2}$ & RMSE & REr \\
\hline \multirow{6}{*}{ Longjing 31} & \multirow{3}{*}{ SE } & RI_NDVI & $Q$ & 0.78 & 0.77 & 0.08 & 6.2 \\
\hline & & RI_NDRE & $\widehat{Q}$ & 0.71 & 0.72 & 0.09 & 6.8 \\
\hline & & RI_VI $I_{\text {opt }}$ & $\mathrm{Q}$ & 0.79 & 0.78 & 0.08 & 6.1 \\
\hline & \multirow{3}{*}{ HD } & RI_NDVI & $\mathrm{Q}$ & 0.92 & 0.65 & 0.12 & 10.2 \\
\hline & & RI_NDRE & $\hat{\mathrm{Q}}$ & 0.92 & 0.75 & 0.10 & 8.4 \\
\hline & & RI_NNIRI & $\widehat{Q}$ & 0.95 & 0.73 & 0.10 & 8.7 \\
\hline \multirow{6}{*}{ Longjing 21} & \multirow{3}{*}{ SE } & RI_NDVI & $Q$ & 0.68 & 0.60 & 0.11 & 7.3 \\
\hline & & RI_NDRE & $\hat{\mathrm{Q}}$ & 0.69 & 0.63 & 0.11 & 7.4 \\
\hline & & RI_REWDRVI & $\hat{\mathrm{Q}}$ & 0.71 & 0.67 & 0.10 & 7.0 \\
\hline & \multirow{3}{*}{$\mathrm{HD}$} & RI_NDVI & $\mathrm{E}$ & 0.67 & 0.60 & 0.16 & 13.4 \\
\hline & & RI_NDRE & Q & 0.79 & 0.82 & 0.10 & 8.7 \\
\hline & & RI_REVI opt $_{\text {op }}$ & Q & 0.79 & 0.82 & 0.10 & 8.7 \\
\hline \multirow{6}{*}{ Across varieties } & \multirow{3}{*}{ SE } & RI_NDVI & $Q$ & 0.67 & 0.61 & 0.11 & 8.0 \\
\hline & & RI_NDRE & $\mathrm{Q}$ & 0.64 & 0.62 & 0.11 & 8.0 \\
\hline & & RI_RVI & $\hat{\mathrm{Q}}$ & 0.68 & 0.63 & 0.11 & 7.8 \\
\hline & \multirow{3}{*}{ HD } & RI_NDVI & Q & 0.79 & 0.62 & 0.14 & 11.5 \\
\hline & & RI_NDRE & $\hat{\mathrm{Q}}$ & 0.85 & 0.78 & 0.10 & 8.3 \\
\hline & & RI_REOSAVI & $\hat{\mathrm{Q}}$ & 0.85 & 0.78 & 0.10 & 8.3 \\
\hline
\end{tabular}

Note: Q, E, and P stand for the quadratic, exponential, and power models. RMSE: root mean square error. REr: relative error (\%).

At the heading stage, RI_NDRE and RI calculated with best performing VIs (normalized NIR index (RI_NNIRI), red edge optimal VI (RI_REVI opt $_{\text {) }}$, REOSAVI (RI_REOSAVI)) performed similarly for the prediction of $\mathrm{RI}_{\text {Harvest }}$ (Table 5). They worked better than RI_NDVI $\left(\mathrm{R}^{2}=0.79-0.85 \mathrm{vs}\right.$. $\left.\mathrm{R}^{2}=0.67-0.79\right)$ for Longjing 21 or across varieties based on the calibration results. However, they performed similarly for Longjing $31\left(R^{2}=0.92-0.95\right)$. With validation, RI_NDRE $\left(R^{2}=0.75-0.82, \operatorname{RMSE}=0.10\right.$ and $\left.\mathrm{REr}=8.3-8.7\right)$ and RI calculated with best performing VIs $\left(R^{2}=0.73-0.82, \mathrm{RMSE}=0.10\right.$ and $\left.\mathrm{REr}=8.3-8.7\right)$ were better than RI_NDVI $\left(R^{2}=0.60-0.65\right.$, RMSE $=0.12-0.16$ and $\left.R E r=10.2-13.4\right)$ for a specific variety or across varieties (Table 5). The RI calculated with best performing VIs performed better at the heading stage than the stem elongation stage for either calibration or validation. 


\section{Stem elongation stage}
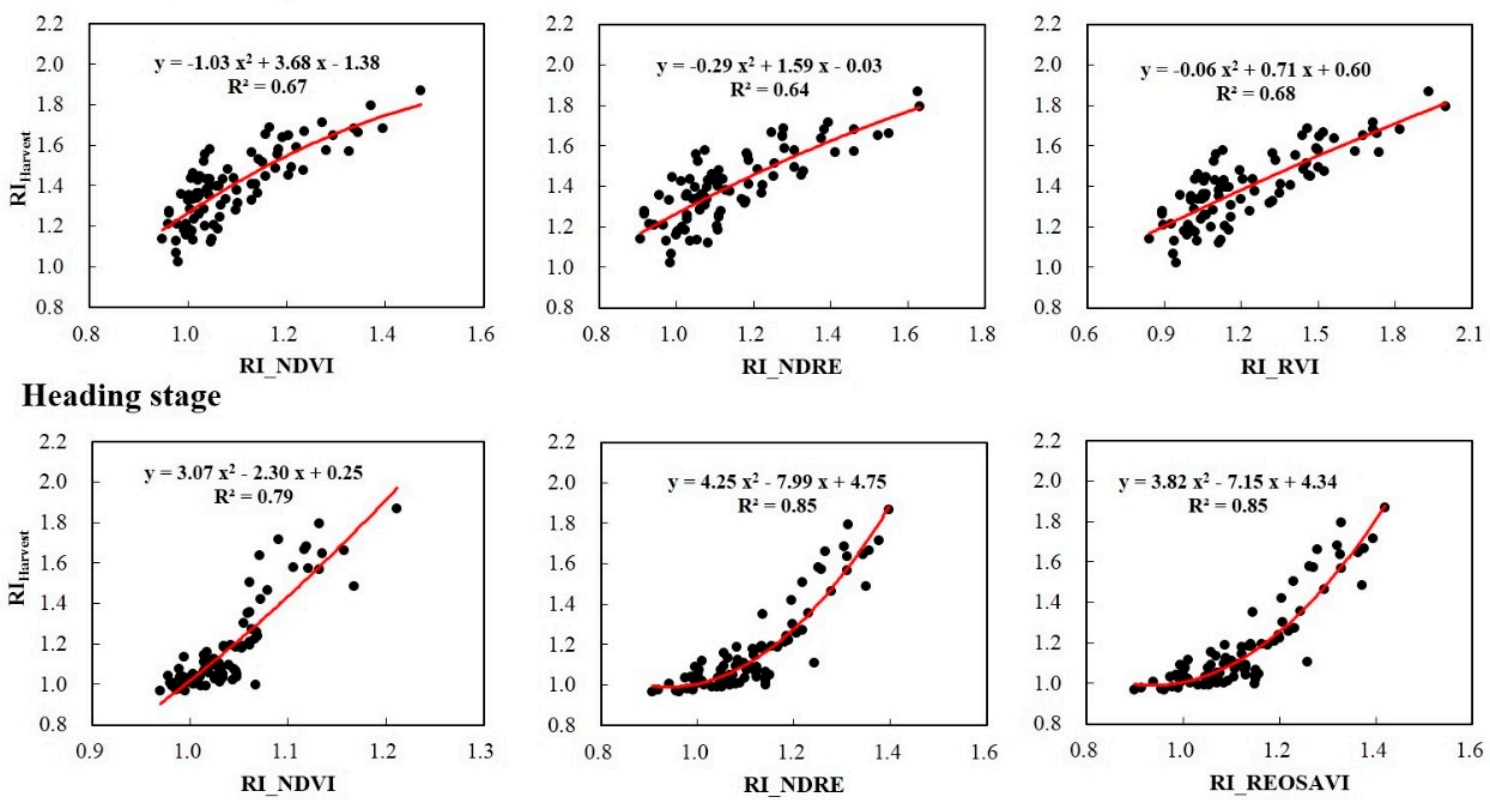

Figure 4. The relationships between response index calculated with yield ( $\left.\mathrm{RI}_{\text {Harvest }}\right)$ and response index calculated with NDVI, NDRE, RVI, and REOSAVI across all varieties at stem elongation stage and heading stage.

\subsection{In-Season Prediction of Nitrogen Use Efficiency}

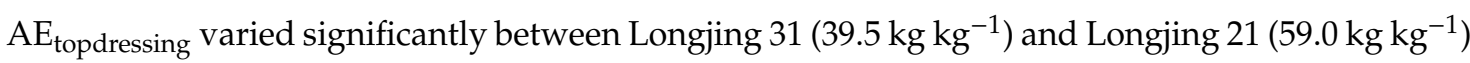
(Figure $5 \mathrm{a}$ ). $\mathrm{RI}_{\text {Harvest }}$ had a strong positive relationship with $\mathrm{AE}_{\text {topdressing, with the correlation being }}$ stronger for Longjing $21\left(R^{2}=0.76\right)$ than for Longjing $31\left(R^{2}=0.61\right)$ (Figure $\left.5 b\right)$. Therefore, in-season predicted $\mathrm{RI}_{\text {Harvest }}$ was used to predict $A E_{\text {topdressing }}$ for side-dress $\mathrm{N}$ fertilizer recommendations in this study.
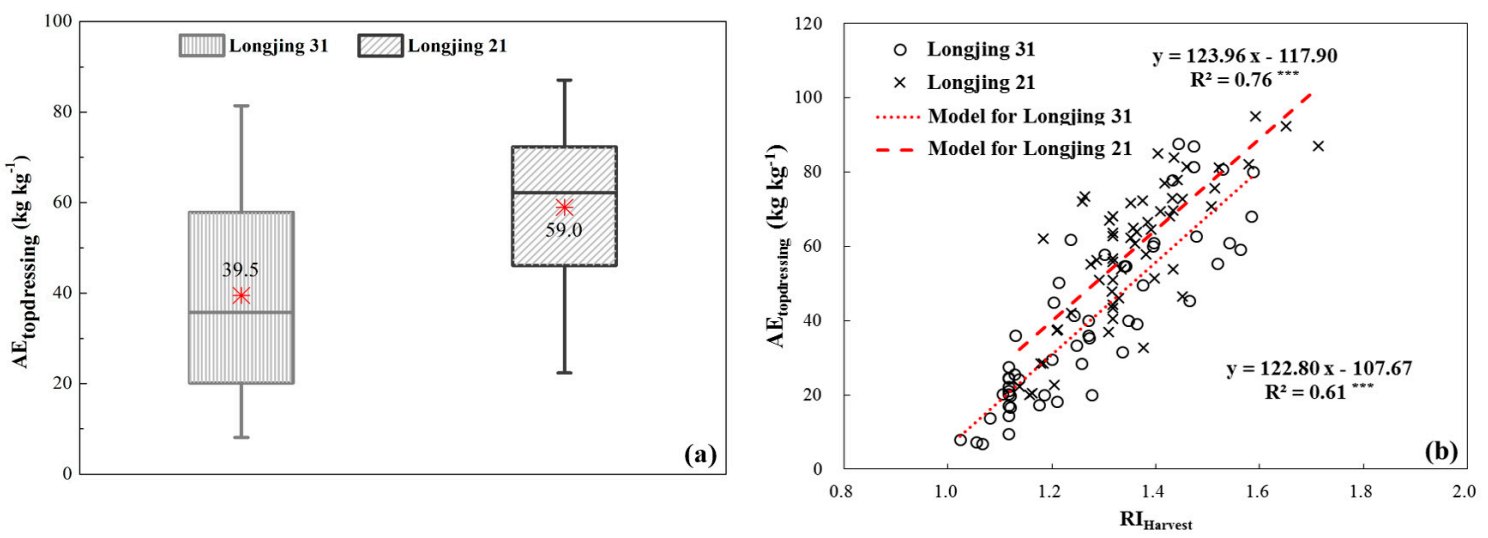

Figure 5. The difference in $\mathrm{AE}_{\text {topdressing }}$ between Longjing 31 and Longjing 21 (a) and its relationship with $\mathrm{RI}_{\text {Harvest }}(\mathbf{b})$. The red $*$ indicates the average of $\mathrm{AE}_{\text {topdressing }}$ in Figure $5 \mathrm{a}$. The red lines are the different regression models for Longjing 31 and Longjing 21 in Figure 5b; ${ }^{* * *}$ indicates significance at the level of $p<0.001$.

\subsection{Evaluating Different Precision Nitrogen Management Strategies Under Variable Nitrogen Status Using} Scenario Analysis

Based on the abovementioned results (Tables 4 and 5), different PNM strategies were developed, as explained in Methods and Figure 3. To evaluate the performance of these strategies under different 
$\mathrm{N}$ status, the $\mathrm{N}$ rate treatments $\left(80,120\right.$, and $\left.160 \mathrm{~kg} \mathrm{ha}^{-1}\right)$ in Exp.1-6 were selected for scenario analysis to determine the difference between recommended $N$ rates $\left(\Delta \mathrm{N}_{\text {rate }}\right)$ based on PNM strategies and EONR calculated using the $\mathrm{N}$ responses in each variety-year (Figures 6-8). The RONM strategy did not consider the variation of years, varieties, and rice $\mathrm{N}$ status, and used a fixed $\mathrm{N}$ topdressing rate $\left(36 \mathrm{~kg} \mathrm{~N} \mathrm{ha}^{-1}\right)$. Four RapidSCAN sensor-based PNM strategies were evaluated. The tested PNM strategies all had the same basal and tillering $\mathrm{N}$ application rates as RONM, but panicle fertilizer at the stem elongation stage was recommended using NDVI or the best performing VIs or panicle and grain fertilizer rates at the stem elongation and heading stages were recommended using NDVI and NDRE or the best performing VIs.
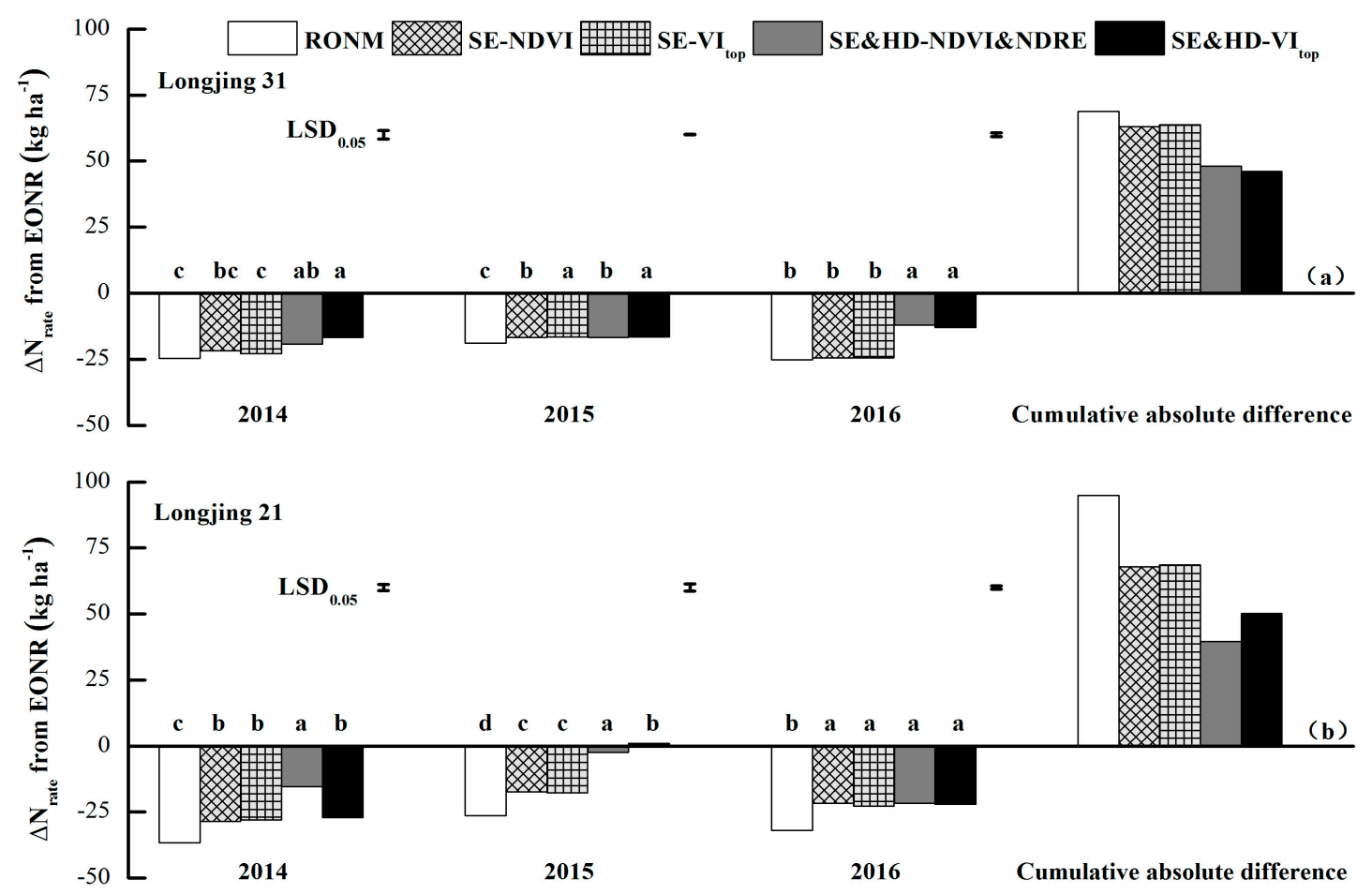

Figure 6. The difference of recommended topdressing $N$ application rate $\left(\Delta \mathrm{N}_{\text {rate }}\right)$ from economically optimal N rates (EONR) between RONM strategy and RapidSCAN sensor-based PNM strategies for the rice varieties of Longjing 31 (a) and Longjing 21 (b) under deficient $\mathrm{N}$ status before topdressing (N80) in 2014-2016. RONM: the regional optimum $\mathrm{N}$ management topdressing $\mathrm{N}$ rate $\left(36 \mathrm{~kg} \mathrm{~N}^{-1}\right.$ in this study). SE-NDVI and SE-VI top indicated recommended topdressing $\mathrm{N}$ application rate calculated by the models based on NDVI and the top performing VIs $\left(\mathrm{VI}_{\text {top }}\right)$ for different varieties at stem elongation stage, respectively. SE\&HD-NDVI\&NDRE and SE\&HD-VI top indicated recommended topdressing N application rates calculated by the models with NDVI (at stem elongation stage) and NDRE (at heading stage), and $\mathrm{VI}_{\text {top }}$ at stem elongation and heading stage, respectively. Vertical bars represent the LSD value $(p=0.05)$. Different letters indicate significant difference at $p<0.05$ level within the same year. 

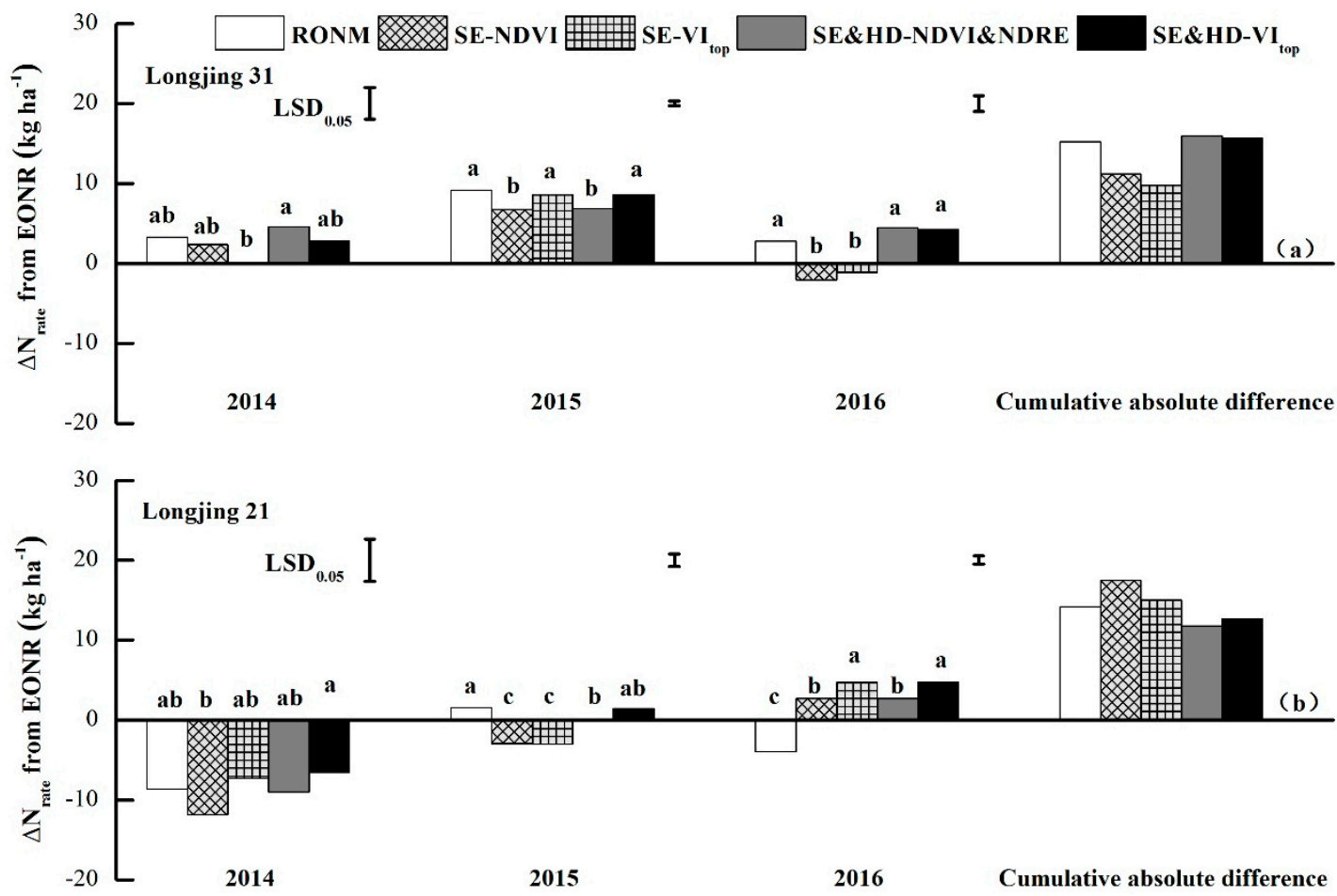

Figure 7. The difference of recommended topdressing $N$ application rate $\left(\Delta \mathrm{N}_{\text {rate }}\right)$ from economically optimal N rates (EONR) between RONM strategy and RapidSCAN sensor-based PNM strategies for the rice varieties of Longjing 31 (a) and Longjing 21 (b) under optimal $\mathrm{N}$ status before topdressing (N120) in 2014-2016. RONM: the regional optimum $\mathrm{N}$ management topdressing $\mathrm{N}$ rate $\left(36 \mathrm{~kg} \mathrm{~N}^{-1}\right.$ in

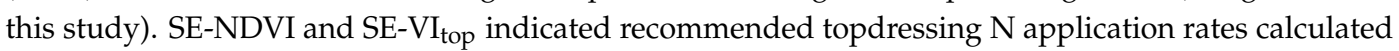
by the models using NDVI and the top performing VIs $\left(\mathrm{VI}_{\mathrm{top}}\right)$ for different varieties at stem elongation stage, respectively. SE\&HD-NDVI\&NDRE and SE\&HD-VI top indicated recommended topdressing $\mathrm{N}$ application rates calculated by the models using NDVI (at stem elongation stage) and NDRE (at heading stage), and $\mathrm{VI}_{\text {top }}$ at stem elongation and heading stage, respectively. Vertical bars represent the LSD value $(p=0.05)$. Different letters indicate significant difference at $p<0.05$ level within the same year.

There were significant differences between RONM and $\mathrm{N}$ rates recommended by different RapidSCAN sensor-based PNM strategies under different years, varieties, and rice $\mathrm{N}$ status. The $\mathrm{N}$ topdressing rate of RONM was consistently lower than EONR under deficient $\mathrm{N}$ status (Figure 6), but higher than EONR under surplus $\mathrm{N}$ conditions (Figure 8). Under relatively optimum $\mathrm{N}$ conditions, RONR was slightly higher than EONR for Longing 31, but lower for Longjing 21 (Figure 7).

All the four PNM strategies recommended higher $\mathrm{N}$ rates than $\mathrm{RONM}$ under deficient $\mathrm{N}$ conditions and lower $\mathrm{N}$ rates under surplus $\mathrm{N}$ conditions, while under relatively optimal $\mathrm{N}$ conditions, the PNM strategies would recommend slightly higher, lower or similar $\mathrm{N}$ rates depending on the year, variety, and PNM strategy. In a specific year across different $\mathrm{N}$ conditions, the $\Delta \mathrm{N}_{\text {rate }}$ for the PNM strategies was in a range of $0-15 \mathrm{~kg} \mathrm{~N} \mathrm{ha}^{-1}$. Among all the four PNM strategies, the PNM strategies based on in-season $\mathrm{N}$ recommendations at both stem elongation and heading stages (with 3-year cumulative $\Delta \mathrm{N}_{\text {rate }}$ of $40-50 \mathrm{~kg} \mathrm{~N} \mathrm{ha}^{-1}$ ) performed better than the PNM strategies making $\mathrm{N}$ recommendation only at the stem elongation stage for Longjing 21 under different $\mathrm{N}$ conditions (with 3-year cumulative $\Delta \mathrm{N}_{\text {rate }}$ of 68-69 $\mathrm{kg} \mathrm{N} \mathrm{ha}^{-1}$ ). For Longjing 31, the PNM strategies making $\mathrm{N}$ recommendations at both stem elongation and heading stages performed much better under deficient $\mathrm{N}$ conditions, with 3-year cumulative $\Delta \mathrm{N}_{\text {rate }}\left(46-48 \mathrm{~kg} \mathrm{~N}^{-1}\right.$ ) being lower than the PNM strategies making $\mathrm{N}$ recommendations only at the stem elongation stage $\left(63-64 \mathrm{~kg} \mathrm{~N} \mathrm{ha}^{-1}\right)$. Irrespective of the varieties, using NDVI and 
NDRE for panicle and grain $\mathrm{N}$ fertilizer recommendations had better or similar performance as the best performing VIs.

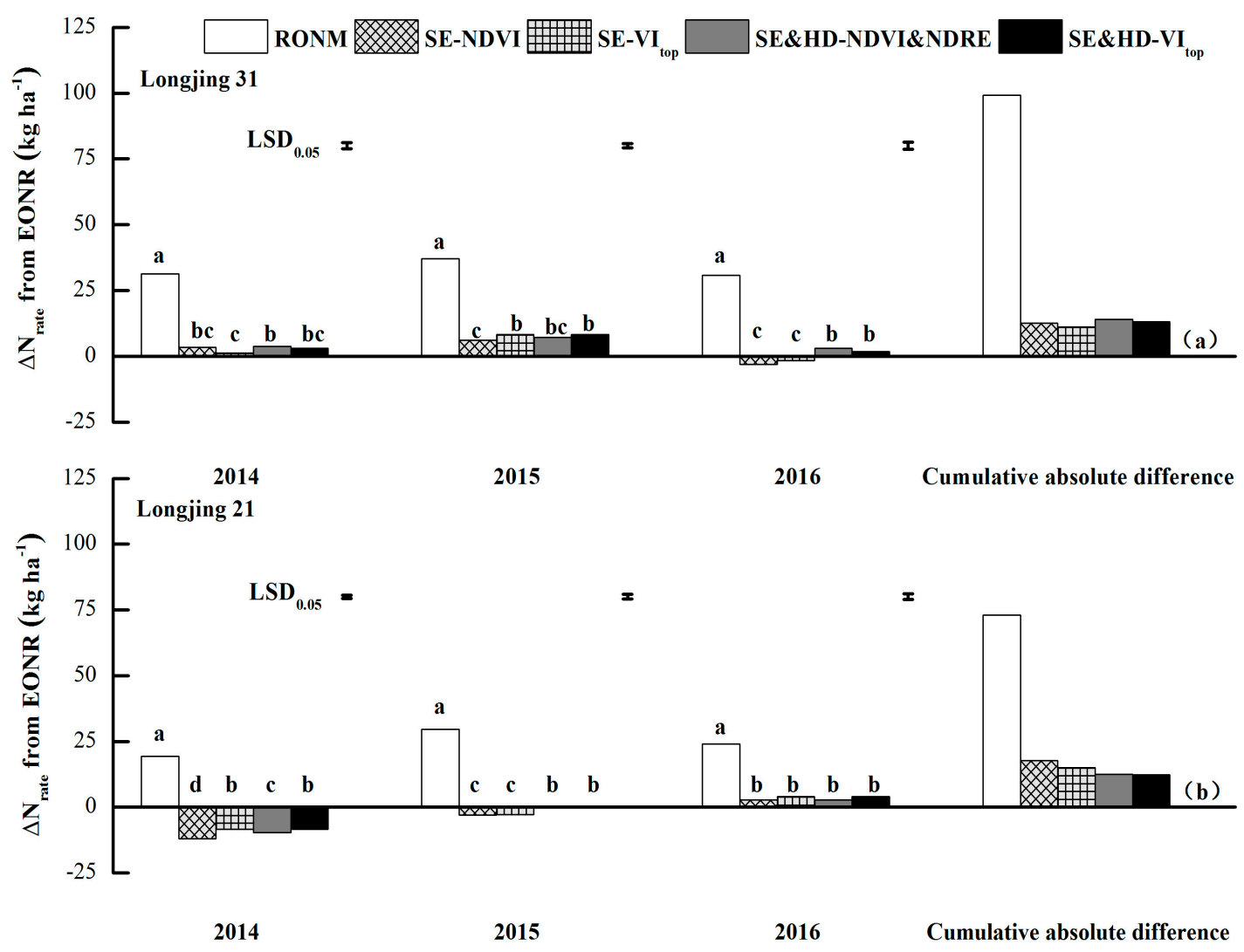

Figure 8. The difference of recommended $N$ topdressing application rate $\left(\Delta N_{\text {rate }}\right)$ from economically optimal N rates (EONR) between RONM strategy and RapidSCAN sensor-based PNM strategies for the rice varieties of Longjing 31 (a) and Longjing 21 (b) under surplus $\mathrm{N}$ status before topdressing (N160) in 2014-2016. RONM: the regional optimum $\mathrm{N}$ management topdressing $\mathrm{N}$ rate $\left(36 \mathrm{~kg} \mathrm{~N}^{-1}\right.$ in

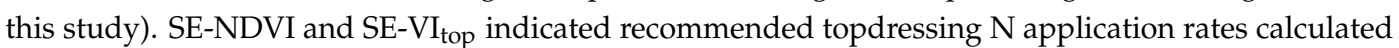
by the models using NDVI and the top performing VIs $\left(\mathrm{VI}_{\mathrm{top}}\right.$ ) for different varieties at stem elongation stage, respectively. SE\&HD-NDVI\&NDRE and SE\&HD-VI top indicated recommended topdressing $\mathrm{N}$ application rates calculated by the models using NDVI (at stem elongation stage) and NDRE (at heading stage), and $\mathrm{VI}_{\text {top }}$ at stem elongation and heading stage, respectively. Vertical bars represent the LSD value $(p=0.05)$. Different letters indicate significant difference at $p<0.05$ level within the same year.

\subsection{Evaluation Experiments}

Based on the above results, we chose NDVI and NDRE for panicle and grain fertilizer recommendation to evaluate the potential of RapidSCAN sensor-based PNM strategy in the evaluation experiments. These experiments included the $0 \mathrm{~kg} \mathrm{~N} \mathrm{ha}^{-1}$ treatment as control (CK), the $160 \mathrm{~kg} \mathrm{~N} \mathrm{ha}^{-1}$ treatment as FNM treatment, the $120 \mathrm{~kg} \mathrm{~N} \mathrm{ha}^{-1}$ treatment as RONM treatment, and RapidSCAN-based PNM treatment in Exp. 2-3 and 5-6 (Table 6). The RapidSCAN sensor-based PNM treatment in evaluation experiments had the same $\mathrm{N}$ rate as RONM (N120) before topdressing and made two in-season adjustments at the stem elongation and heading growth stages. 
Table 6. $\mathrm{N}$ application rate $\left(\mathrm{N}_{\text {rate }}\right)$, grain yield, agronomy efficiency of $\mathrm{N}\left(\mathrm{AE}_{\mathrm{N}}\right)$, partial factor productivity of $\mathrm{N}\left(\mathrm{PFP}_{\mathrm{N}}\right)$, and economic returns of different rice $\mathrm{N}$ management strategies in the evaluation experiments conducted in 2015 and 2016.

\begin{tabular}{|c|c|c|c|c|c|c|c|c|}
\hline & \multirow{2}{*}{ Treatment } & \multicolumn{2}{|c|}{2015} & \multicolumn{2}{|c|}{2016} & \multicolumn{3}{|c|}{ Across Two Years } \\
\hline & & Longjing 31 & Longjing 21 & Longjing 31 & Longjing 21 & Longjing 31 & Longjing 21 & Average \\
\hline \multirow{4}{*}{$\mathrm{N}_{\text {rate }}\left(\mathrm{kg} \mathrm{ha}^{-1}\right)$} & CK & 0 & 0 & 0 & 0 & 0 & 0 & 0 \\
\hline & FNM & 160 & 160 & 160 & 160 & 160 & 160 & 160 \\
\hline & RONM & 120 & 120 & 120 & 120 & 120 & 120 & 120 \\
\hline & PNM & 118 & 119 & 122 & 127 & 120 & 123 & 121 \\
\hline \multirow{4}{*}{ Yield $\left(\mathrm{t} \mathrm{ha}^{-1}\right)$} & CK & $5.26 \mathrm{~b}$ & $5.46 \mathrm{~b}$ & $5.25 \mathrm{~b}$ & $5.17 \mathrm{c}$ & $5.25 \mathrm{c}$ & $5.31 \mathrm{c}$ & $5.28 \mathrm{c}$ \\
\hline & FNM & $8.19 \mathrm{a}$ & $8.60 \mathrm{a}$ & $8.40 \mathrm{a}$ & $8.90 \mathrm{ab}$ & $8.30 \mathrm{a}$ & $8.75 a b$ & $8.52 \mathrm{a}$ \\
\hline & RONM & $7.78 \mathrm{a}$ & $8.36 \mathrm{a}$ & $8.05 \mathrm{a}$ & $8.68 \mathrm{~b}$ & $7.91 \mathrm{~b}$ & $8.52 \mathrm{~b}$ & $8.22 \mathrm{~b}$ \\
\hline & PNM & $8.14 \mathrm{a}$ & $8.59 \mathrm{a}$ & $8.43 \mathrm{a}$ & $9.06 \mathrm{a}$ & $8.29 \mathrm{a}$ & $8.83 \mathrm{a}$ & $8.56 \mathrm{a}$ \\
\hline \multirow{4}{*}{$\mathrm{AE}_{\mathrm{N}}\left(\mathrm{kg} \mathrm{kg}^{-1}\right)$} & CK & - & - & - & - & - & - & - \\
\hline & FNM & $18.3 \mathrm{~b}$ & $19.6 \mathrm{c}$ & $19.7 \mathrm{c}$ & $23.3 \mathrm{~b}$ & $19.0 \mathrm{c}$ & $21.5 \mathrm{c}$ & $20.3 c$ \\
\hline & RONM & $21.0 \mathrm{ab}$ & $24.2 \mathrm{~b}$ & $23.3 \mathrm{~b}$ & $29.3 \mathrm{a}$ & $22.2 \mathrm{~b}$ & $26.8 \mathrm{~b}$ & $24.5 \mathrm{~b}$ \\
\hline & PNM & $24.4 \mathrm{a}$ & $26.4 \mathrm{a}$ & $26.1 \mathrm{a}$ & $30.8 \mathrm{a}$ & $25.3 \mathrm{a}$ & $28.6 \mathrm{a}$ & $26.9 \mathrm{a}$ \\
\hline \multirow{4}{*}{$\operatorname{PFP}_{\mathrm{N}}\left(\mathrm{kg} \mathrm{kg}^{-1}\right)$} & CK & - & - & - & - & - & - & - \\
\hline & FNM & $51.2 \mathrm{c}$ & $53.7 \mathrm{c}$ & $52.5 \mathrm{c}$ & $55.6 \mathrm{~b}$ & $51.9 \mathrm{c}$ & $54.7 \mathrm{~b}$ & $53.3 \mathrm{c}$ \\
\hline & RONM & $64.8 \mathrm{~b}$ & $69.7 \mathrm{~b}$ & $67.1 \mathrm{~b}$ & $72.3 \mathrm{a}$ & $65.9 \mathrm{~b}$ & $71.0 \mathrm{a}$ & $68.5 \mathrm{~b}$ \\
\hline & PNM & 68.9 a & $72.4 \mathrm{a}$ & $69.1 \mathrm{a}$ & $71.6 \mathrm{a}$ & $69.0 \mathrm{a}$ & $72.0 \mathrm{a}$ & $70.5 \mathrm{a}$ \\
\hline \multirow{4}{*}{ Economic return $\left(\$ \mathrm{ha}^{-1}\right)$} & CK & - & - & - & - & - & - & - \\
\hline & FNM & $1205 \mathrm{a}$ & $1297 \mathrm{a}$ & $1300 \mathrm{a}$ & $1556 \mathrm{a}$ & $1253 \mathrm{a}$ & $1426 \mathrm{a}$ & $1339 \mathrm{a}$ \\
\hline & RONM & $1045 \mathrm{a}$ & $1214 \mathrm{a}$ & $1166 \mathrm{a}$ & $1481 \mathrm{a}$ & $1106 \mathrm{~b}$ & $1348 \mathrm{~b}$ & $1227 \mathrm{~b}$ \\
\hline & PNM & $1205 \mathrm{a}$ & $1315 \mathrm{a}$ & $1334 \mathrm{a}$ & $1647 \mathrm{a}$ & $1269 \mathrm{a}$ & $1481 \mathrm{a}$ & 1375 a \\
\hline
\end{tabular}

Note: CK: the control treatment with no $\mathrm{N}$ application; RONM: regional optimum $\mathrm{N}$ management; FNM: farmer $\mathrm{N}$ management; PNM: RapidSCAN-based precision N management strategy. Within a column for parameter, values followed by different letters are significantly different $(p<0.05)$.

Making two in-season $\mathrm{N}$ recommendations to better meet rice $\mathrm{N}$ requirements, the RapidSCAN-based PNM strategy recommended different $\mathrm{N}$ rates for different years and varieties. For Longjing 31, the total recommended $\mathrm{N}$ rates by the PNM strategy were $118-122 \mathrm{~kg} \mathrm{~N} \mathrm{ha}{ }^{-1}$, which were similar to the rates of the RONM strategy but 24-26\% lower than the N rates of the FNM strategy. For Longjing 21, the total $\mathrm{N}$ rates recommended by the PNM strategy were similar to or higher than the rates given by the RONM strategy but $21-26 \%$ lower than the $\mathrm{N}$ rate of the FNM strategy (Table 6).

The RapidSCAN-based PNM strategy resulted in higher yield than RONM strategy across years and varieties. For Longjing 31, the yield of the PNM strategy was not significantly different from FNM and RONM strategies in a specific year, but it was significantly higher (5\%) than the RONM strategy across two years. For Longjing 21, the PNM strategy significantly increased grain yield by $4 \%$ with respect to the RONM strategy in 2016 or across two years, but the increase was not significantly different from the FNM strategy.

The PNM strategy led to the highest $\mathrm{AE}_{\mathrm{N}}$ and $\mathrm{PFP}_{\mathrm{N}}$ across years and varieties. For Longjing 31, the PNM strategy increased $\mathrm{AE}_{\mathrm{N}}$ and $\mathrm{PFP}_{\mathrm{N}}$ by $14 \%$ and $5 \%$ over the RONM strategy and both by $33 \%$ over the FNM strategy across two years, respectively. For Longing 21, the PNM strategy increased $\mathrm{AE}_{\mathrm{N}}$ by $33 \%$ and $\mathrm{PFP}_{\mathrm{N}}$ by $32 \%$ over the FNM strategy across two years. Compared with RONM, the PNM strategy increased $\mathrm{AE}_{\mathrm{N}}$ by $7 \%$, but did not improve $\mathrm{PFP}_{\mathrm{N}}$ significantly. Across varieties and years, the PNM strategy increased $\mathrm{AE}_{\mathrm{N}}$ and $\mathrm{PFP}_{\mathrm{N}}$ by $32-33 \%$ over $\mathrm{FNM}$ and by $3-10 \%$ over RONM.

The PNM strategy consistently increased economic returns compared with RONM by 101-168 $\$ h^{-1}$ for specific year-variety combination or across years and varieties. The PNM strategy increased economic returns by 0-91 \$ ha ${ }^{-1}$ over the FNM strategy, but none of the increase was statistically significant. 


\section{Discussion}

\subsection{Selection of Vegetation Indices for Precision N Management Strategy Development}

NDVI and NDRE are two widely used VIs in precision agriculture and have good relationships with aboveground biomass and plant $\mathrm{N}$ uptake [14,32]. They are the default VIs of the RapidSCAN sensor, and increased with $\mathrm{N}$ application rates in this study, which was in agreement with Aranguren et al. [33]. Besides NDVI and NDRE, many other VIs can be calculated from the three wavebands of RapidSCAN [13,34]. It is important to know if any other VI will perform consistently better than the default VIs and should be selected for PNM strategy development.

In this study, we found that the two default indices (NDVI and NDRE) were sufficient for estimating key parameters to develop the PNM strategy at different key growth stages and other VIs would not be needed.

The stem elongation stage is the key stage to apply panicle fertilizer for rice in Northeast China. The rice canopy was not closed at this stage, and the biomass was not very high yet. The NDVI values were not saturated and achieved similar performance for predicting $\mathrm{YP}_{0}\left(\mathrm{R}^{2}=0.66-0.70 ; \mathrm{REr}=6.3-7.7 \%\right)$ and $\mathrm{RI}_{\text {Harvest }}\left(\mathrm{R}^{2}=0.60-0.77 ; \mathrm{REr}=6.2-8.0 \%\right)$ as best performing $\mathrm{VIs}\left(\mathrm{R}^{2}=0.63-0.70\right.$ and $0.63-0.78 ; \mathrm{REr}$ $=6.5-7.6 \%$ and $6.1-7.8 \%$, respectively). The recommended $\mathrm{N}$ rates using NDVI were also similar to the best performing VIs across both varieties based on the scenario analysis results. This agreed with many studies achieving good results with GreenSeeker NDVI-based PNM systems at early growth stages [10,12,34-38].

The heading stage is the key stage to apply grain fertilizer for rice in Northeast China in high-yield rice management systems [13,16]. GreenSeeker NDVI become saturated at this stage and cannot be used to make $\mathrm{N}$ recommendations $[10,13,16,34,39]$. As a result, the PNM strategy making two in-season $\mathrm{N}$ recommendations at stem elongation and heading stages only using NDVI had the worst performance among all the PNM strategies evaluated in the scenario analysis. One approach to overcome the NDVI saturation problem is to combine NDVI with relative plant height data [30]. Another approach is to replace NDVI with other VIs that can overcome the saturation effect [32]. The RapidSCAN sensor has a RE band in addition to the R and NIR bands, which can be used to calculate more RE-based VIs to overcome the saturation problems of NDVI [13,14,40]. In this study, good relationships between RE-based VIs and $\mathrm{YP}_{0}$ or $\mathrm{RI}_{\text {Harvest }}$ were found at the heading stage, with $\mathrm{R}^{2}$ being $0.75-0.95$ for calibration, and $\mathrm{R}^{2}$ and $\mathrm{REr}$ being $0.70-0.82$ and $7.3-9.0 \%$ for validation, respectively. Encouragingly, the NDRE index achieved similar performance for predicting $\mathrm{YP}_{0}\left(\mathrm{R}^{2}=0.70-0.76\right.$; $\mathrm{REr}$ $=7.3-8.6 \%)$ and $\mathrm{RI}_{\text {Harvest }}\left(\mathrm{R}^{2}=0.75-0.82 ; \mathrm{REr}=8.3-8.7 \%\right)$ as best performing VIs $\left(\mathrm{R}^{2}=0.70-0.76\right.$ and $0.73-0.82 ; \mathrm{REr}=7.3-9.0 \%$ and $8.3-8.7 \%$, respectively). Furthermore, the $\mathrm{N}$ rates recommended by the PNM strategy using NDVI at the stem elongation stage and NDRE at heading stage were very similar to the $\mathrm{N}$ rates recommended by the PNM strategy using best performing VIs at the stem elongation and heading stages.

\subsection{In-Season Prediction of Agronomic Efficiency of Topdressing Nitrogen}

The NUE is an important parameter for developing crop sensing-based PNM strategies, and can directly influence the final recommended N rates. Previous crop sensor-based PNM strategies generally used a constant NUE value. Raun et al. [12] used the expected recovery efficiency to calculate the $\mathrm{N}$ topdressing rate for wheat with the range of 0.5 to 0.7 in America. Cao et al. [34] used 0.4 as the expected recovery efficiency in developing PNM strategy for winter wheat in North China Plain. According to the multi-site-year data in $\mathrm{N}$ plot experiments, Yao et al. [10] used fixed $\mathrm{AE}_{\text {topdressing }}$ $\left(26.79 \mathrm{~kg} \mathrm{~kg}^{-1}\right)$ for the development of rice PNM strategy.

Studies indicated that NUE is influenced by environmental factors (e.g., soil fertility, water supply, sunshine, accumulated temperature, etc.) and the plant genotypes (e.g., ability to absorb $\mathrm{N}$, photosynthetic rate, stress resistance, root system structure, etc.) [41-44]. Wang et al. [30] considered the influence of early $\mathrm{N}$ application and soil types on $\mathrm{AE}_{\mathrm{N}}$ and used in-season predicted $\mathrm{RI}_{\text {Harvest }}$ 
with GreenSeeker sensor to predict $\mathrm{AE}_{\mathrm{N}}$ for developing crop sensor-based PNM strategy for spring maize in Northeast China. Following their idea, this study found that early $\mathrm{N}$ application and rice variety were two key factors influencing the $\mathrm{AE}_{\text {topdressing }}$ of rice in the study region. If early season $\mathrm{N}$ application rate is low, $\mathrm{N}$ deficiency will lead to a higher efficiency of $\mathrm{N}$ use, while a high $\mathrm{N}$ application rate during the early growth stage will result in $\mathrm{N}$ surplus conditions before topdressing, which will lead to a lower use efficiency of the topdressing $\mathrm{N}$ fertilizer. $\mathrm{RI}_{\text {Harvest }}$ is an indicator of crop $\mathrm{N}$ response to additional $\mathrm{N}$ application. If early season $\mathrm{N}$ status is deficient, the crop will be more responsive to additional topdressing or side-dressing $\mathrm{N}$ application. On the other hand, if the early season $\mathrm{N}$ status is surplus, the crop will not be responsive to additional $\mathrm{N}$ application, and the NUE for the topdressing or side-dressing $\mathrm{N}$ application will be lower. Therefore, the $\mathrm{RI}_{\text {Harvest }}$ and $\mathrm{AE}_{\text {topdressing }}$ should be positively correlated, as found in this study $\left(\mathrm{R}^{2}=0.61 \sim 0.76\right)$. This finding was consistent with the results of Wang et al. [30] for spring maize $\left(\mathrm{R}^{2}=0.72 \sim 0.74\right)$. On the other hand, the big difference of

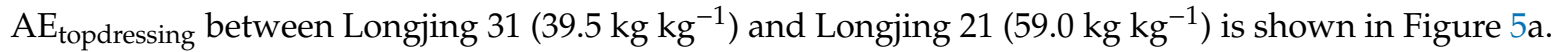
The variety with longer growing period will require more $\mathrm{N}$ supply and the photosynthetic utilization will be higher. Therefore, in-season prediction of $\mathrm{AE}_{\text {topdressing }}$ can be based on crop $\mathrm{N}$ status using in-season active sensor predicted response index and variety- or variety group-specific models should be developed.

\subsection{Evaluation of Different Precision N Management Strategies}

In scenario analysis, the four PNM strategies for $\mathrm{N}$ rate recommendations performed much better than the RONM strategy, especially under deficient or surplus N status. The PNM strategies making two in-season $\mathrm{N}$ recommendations at both stem elongation and heading stages performed better than PNM strategies making only one in-season $\mathrm{N}$ recommendation at the stem elongation stage, and their recommended $\mathrm{N}$ rates were $15-28 \mathrm{~kg} \mathrm{~N}$ ha $^{-1}$ closer to EONR under deficient $\mathrm{N}$ status across years and varieties. For the longer-growing variety (Longjing 21), the PNM strategy making two N recommendations performed consistently better under different $\mathrm{N}$ conditions, being $2-28 \mathrm{~kg} \mathrm{~N} \mathrm{ha}^{-1}$ closer to EONR across years. However, no significant difference was found under optimal or surplus $\mathrm{N}$ status for Longjing 31, the shorter-growing variety. One of the reasons might be that Longjing 21 typically required a higher $\mathrm{N}$ rate and more time (3-7 days) to booting and grain filling than Longjing 31 [9]. The PNM strategy with two in-season $\mathrm{N}$ recommendations can give us two opportunities to adjust $\mathrm{N}$ application rates according to in-season crop growth and weather conditions, and can better meet rice $\mathrm{N}$ needs to increase grain yield. This is more important for the long-season variety Longjing 21 than the shorter-season variety of Longjing 31 [45].

In the evaluation experiments, the RapidSCAN-based PNM strategy could achieve similar rice yield as the FNM strategy, save $24 \% \mathrm{~N}$ fertilizers, and increase NUE by an average of 32-33\% across years and varieties (Table 6). Because of the low $\mathrm{N}$ fertilizer prices under agricultural subsidies by the government in China, the difference of economic return between PNM and FNM was small (average 36 $\$$ ha $^{-1}$ annually) across varieties. These results agreed with the results of Yao et al. [10], who reported that PNM strategies based on GreenSeeker or chlorophyll meter increased $\mathrm{PFP}_{\mathrm{N}}$ by $48-65 \%$ without significantly increasing the yield in comparison to FNM.

Although the total $\mathrm{N}$ rates of PNM and RONM strategies in the evaluation experiments were not significantly different, the PNM strategy allowed us to better adjust $\mathrm{N}$ distribution for different varieties and plant $\mathrm{N}$ status, resulting in the increased grain yield, $\mathrm{AE}_{\mathrm{N}}, \mathrm{PFP}_{\mathrm{N}}$, and economic return by an average of $4 \%, 10 \%, 3 \%$, and $148 \$$ ha $^{-1}$,respectively (Table 6). Zhao et al. [16] found that a chlorophyll meter-based PNM with two in-season $\mathrm{N}$ recommendations at the same growth stages as the PNM strategy developed in this study had higher $\mathrm{N}$ accumulation at later growth stages to achieve higher yield, and larger panicle size and grain fill percentage. Wang et al. [45] integrated a GreenSeeker sensor-based PNM strategy making one in-season $\mathrm{N}$ recommendation at stem elongation stage into a high-yield management system (with optimized transplanting density and water management) increased rice grain yield and NUE by $10 \%$ and $1-33 \%$ over regional optimum rice management, 
respectively. Future studies are needed to integrate the RapidSCAN sensor-based PNM strategy developed in this study into similar high-yield management systems to further evaluate its potential to simultaneously improve rice yield, NUE, and economic returns over the regional optimum management system under diverse on-farm conditions.

\section{Conclusions}

The RapidSCAN sensor has the potential to predict rice grain yield and response to additional $\mathrm{N}$ application in Northeast China at the stem elongation and heading stages during the growing season, with $\mathrm{R}^{2}$ and $\mathrm{REr}$ being $0.63-0.82$ and 6.1-9.0\%, respectively. At the stem elongation stage, NDVI could be used to predict $\mathrm{YP}_{0}$ and $\mathrm{RI}_{\text {Harvest }}\left(\mathrm{R}^{2}=0.66-0.70\right.$ and $0.60-0.77 ; \mathrm{REr}=6.3-7.7 \%$ and $6.2-8.0 \%)$ with similar performance as the best performing indices $\left(\mathrm{R}^{2}=0.63-0.70\right.$ and $0.63-0.78 ; \mathrm{REr}=$ $6.5-7.6 \%$ and $6.1-7.8 \%$, respectively). At the heading stage, NDRE could be used to predict $\mathrm{YP}_{0}$ and $\mathrm{RI}_{\text {Harvest }}\left(\mathrm{R}^{2}=0.70-0.76\right.$ and $0.75-0.82 ; \mathrm{REr}=7.3-8.6 \%$ and $8.3-8.7 \%$, respectively) as accurately as the best performing indices $\left(\mathrm{R}^{2}=0.70-0.76\right.$ and $0.73-0.82 ; \mathrm{REr}=7.3-9.0 \%$ and $8.3-8.7 \%$, respectively). The combination of the two default indices (NDVI and NDRE) of the RapdiSCAN sensor was sufficient for rice PNM strategy development without the need of incorporating other indices. Across the two tested varieties under deficient $\mathrm{N}$ conditions or for Longjing 21 under different $\mathrm{N}$ conditions, the PNM strategy making two in-season $\mathrm{N}$ recommendations performed better than the PNM strategies making only one in-season $\mathrm{N}$ recommendation at the stem elongation stage. The RapidSCAN sensor-based PNM strategy with panicle and grain fertilizer recommendations could lead to similar yield as FNM, save $24 \% \mathrm{~N}$ application rate, and increase $\mathrm{AE}_{\mathrm{N}}$ and $\mathrm{PFP}_{\mathrm{N}}$ by an average of $33 \%$ and $32 \%$ across years and varieties, respectively. Compared with RONM, the PNM strategy increased grain yield, $\mathrm{AE}_{\mathrm{N}}$, $\mathrm{PFP}_{\mathrm{N}}$, and economic return by an average of $4 \%, 10 \%, 3 \%$, and $148 \$ \mathrm{ha}^{-1}$ across years and varieties, respectively. Future studies are needed to further evaluate the RapidSCAN sensor-based PNM strategy under diverse on-farm conditions, and integrate it into high-yield rice management systems.

Author Contributions: Conceptualization, J.L. (Junjun Lu) and Y.M.; methodology and validation, Y.M., J.L. (Junjun Lu), and X.W.; investigation, J.L. (Junjun Lu), W.S., J.L. (Jingxin Li), and X.H.; resources: Y.M., and J.L. (Junjun Lu); writing — original draft preparation, J.L. (Junjun Lu); writing-review and editing, Y.M., K.K. and Z.C.; supervision, Y.M.; project administration and funding acquisition, Y.M., J.L. (Junjun Lu), and K.K. All authors have read and agreed to the published version of the manuscript.

Funding: This research was funded by the Key National Research and Development Program (2016YFD0200600; 2016YFD0200602), Norwegian Ministry of Foreign Affairs (SINOGRAIN II, CHN-17/0019), Doctoral Foundation of Henan Polytechnic University (B2019-5), Key Scientific Research Projects of Universities Supported by Foundation of Henan Educational Committee (20A210013), and Key Scientific and Technological Project of Henan Province (192102310038).

Acknowledgments: The kind assistance and support provided for this research by Yuan Gao, Wen Yang, Yong Yang, Haisheng He, Honglin Li, Fengyan Liu, and Xiaolong Wang at Jiansanjiang Institute of Agricultural Research and Mr. Guojun Li from Jiansanjiang Department of Agriculture, Jiansanjiang Branch Bureau of Agricultural Reclamation are highly appreciated.

Conflicts of Interest: The authors declare no conflict of interest. 
Abbreviations

\begin{tabular}{|c|c|c|}
\hline Abbreviation & English Full Name & Unit \\
\hline $\mathrm{AE}_{\mathrm{N}}$ & Agronomic efficiency of nitrogen & $\%$ \\
\hline FNM & Farmer nitrogen management & - \\
\hline HD_N $\mathrm{Nate}_{\text {r }}$ & The recommended nitrogen topdressing application rate at the heading stage & $\mathrm{kg} \mathrm{N} \mathrm{ha}^{-1}$ \\
\hline HD_YP $\mathrm{N}_{\mathrm{N}}$ & The potential yield with added nitrogen topdressing application at the heading stage & $\mathrm{kg} \mathrm{ha}^{-1}$ \\
\hline $\mathrm{N}$ & Nitrogen & - \\
\hline NDRE & Normalized difference red edge & - \\
\hline NDVI & Normalized difference vegetation index & - \\
\hline NIR & Near infrared & - \\
\hline $\mathrm{N}_{\text {rate }}$ & The recommended $\mathrm{N}$ topdressing application rate & $\mathrm{kg} \mathrm{N} \mathrm{ha}^{-1}$ \\
\hline NUE & Nitrogen use efficiency & - \\
\hline $\mathrm{R}$ & Red & - \\
\hline $\mathrm{R}^{2}$ & The coefficients of determination & - \\
\hline RE & Red edge & - \\
\hline REr & Relative error & $\%$ \\
\hline $\mathrm{RI}_{\text {Harvest }}$ & Yield responsiveness to additional nitrogen fertilizer applications & - \\
\hline RI-VI & In-season nitrogen response index based on vegetation index & - \\
\hline RMSE & The root mean square error & $\begin{array}{c}\text { Same units as } \\
\text { statistical data used }\end{array}$ \\
\hline RONM & Regional optimum nitrogen management & - \\
\hline RVI & Ratio vegetation index & - \\
\hline SE_N $\mathrm{N}_{\text {rate }}$ & The recommended nitrogen topdressing application rate at the stem elongation stage & $\mathrm{kg} \mathrm{N} \mathrm{ha}^{-1}$ \\
\hline $\mathrm{YP}_{\max }$ & The maximum obtainable yield & $\mathrm{kg} \mathrm{ha}^{-1}$ \\
\hline $\mathrm{YP}_{\mathrm{N}}$ & The potential yield with added nitrogen fertilization & $\mathrm{kg} \mathrm{ha}^{-1}$ \\
\hline$\Delta \mathrm{N}_{\text {rate }}$ & The difference between recommended nitrogen rate and economically optimum nitrogen rate & $\mathrm{kg} \mathrm{N} \mathrm{ha}^{-1}$ \\
\hline
\end{tabular}

\section{References}

1. Cantrell, R.P.; Reeves, T.G. The cereal of the world's poor takes center stage. Science 2002, 296, 53. [CrossRef] [PubMed]

2. Normile, D. Reinventing rice to feed the world. Science 2008, 321, 330-333. [CrossRef] [PubMed]

3. Foley, J.A.; Ramankutty, N.; Brauman, K.A.; Cassidy, E.S.; Gerber, J.S.; Johnston, M.; Mueller, N.D.; O'Connell, C.; Ray, D.K.; West, P.C.; et al. Solutions for a cultivated planet. Nature 2011, 478, 337-342. [CrossRef] [PubMed]

4. Zhang, F; Chen, X.; Vitousek, P. Chinese agriculture: An experiment for the world. Nature 2013, 497, 33-35. [CrossRef] [PubMed]

5. Peng, X.; Yang, Y.; Yu, C.; Chen, L.; Zhang, M.; Liu, Z.; Sun, Y.; Luo, S.; Liu, Y. Crop management for increasing rice yield and nitrogen use efficiency in Northeast China. Agron. J. 2015, 107, 1682-1690. [CrossRef]

6. Wu, L.; Chen, X.; Cui, Z.; Wang, G.; Zhang, W. Improving nitrogen management via a regional management plan for Chinese rice production. Environ. Res. Lett. 2015, 10, 095011. [CrossRef]

7. Chen, X.; Cui, Z.; Fan, M.; Vitousek, P.; Zhao, M.; Ma, W.; Wang, Z.; Zhang, W.; Yan, X.; Yang, J. Producing more grain with lower environmental costs. Nature 2014, 514, 486-489. [CrossRef]

8. Cao, Q.; Miao, Y.; Feng, G.; Gao, X.; Liu, B.; Liu, Y.; Li, F.; Khosla, R.; Mulla, D.J.; Zhang, F. Improving nitrogen use efficiency with minimal environmental risks using an active canopy sensor in a wheat-maize cropping system. Field Crop. Res. 2017, 214, 365-372. [CrossRef]

9. Zhang, J.; Miao, Y.; Batchelor, W.; Lu, J.; Wang, H.; Kang, S. Improving high-latitude rice nitrogen management with the CERES-rice crop model. Agronomy 2018, 8, 263. [CrossRef] 
10. Yao, Y.; Miao, Y.; Huang, S.; Gao, L.; Ma, X.; Zhao, G.; Jiang, R.; Chen, X.; Zhang, F.; Yu, K.; et al. Active canopy sensor-based precision N management strategy for rice. Agron. Sustain. Dev. 2012, 32, 925-933. [CrossRef]

11. Raun, W.R.; Solie, J.B.; Johnson, G.V.; Stone, M.L.; Mullen, R.W.; Freeman, K.W.; Thomason, W.E.; Lukina, E.V. Improving nitrogen use efficiency in cereal grain production with optical sensing and variable rate application. Agron. J. 2002, 94, 815-820. [CrossRef]

12. Raun, W.R.; Solie, J.B.; Stone, M.L.; Martin, K.L.; Freeman, K.W.; Mullen, R.W.; Zhang, H.; Schepers, J.S.; Johnson, G.V. Optical sensor-based algorithm for crop nitrogen fertilization. Commun. Soil Sci. Plan. 2005, 36, 2759-2781. [CrossRef]

13. Cao, Q.; Miao, Y.; Shen, J.; Yu, W.; Yuan, F.; Cheng, S.; Huang, S.; Wang, H.; Yang, W.; Liu, F. Improving in-season estimation of rice yield potential and responsiveness to topdressing nitrogen application with Crop Circle active crop canopy sensor. Precis. Agric. 2016, 17, 136-154. [CrossRef]

14. Lu, J.; Miao, Y.; Shi, W.; Li, J.; Yuan, F. Evaluating different approaches to non-destructive nitrogen status diagnosis of rice using portable RapidSCAN active canopy sensor. Sci. Rep. 2017, 7, 14073. [CrossRef] [PubMed]

15. Zhang, K.; Ge, X.; Shen, P.; Li, W.; Liu, X.; Cao, Q.; Zhu, Y.; Cao, Q.; Tian, Y. Predicting rice grain yield based on dynamic changes in vegetation indexes during early to mid-growth stages. Remote Sens. 2019, 11, 387. [CrossRef]

16. Zhao, G.; Miao, Y.; Wang, H.; Su, M.; Fan, M.; Zhang, F.; Jiang, R.; Zhang, Z.; Liu, C.; Liu, P.; et al. A preliminary precision rice management system for increasing both grain yield and nitrogen use efficiency. Field Crop. Res. 2013, 154, 23-30. [CrossRef]

17. Xing, B.; Dudas, M.J.; Zhang, Z.; Xu, Q. Pedogenetic characteristics of albic soils in the Three River Plain, Heilongjiang province. Acta. Pedolog. Sin. 1994, 31, 95-104, (In Chinese with English Abstract).

18. Rouse, J.W.; Haas, J.R.H.; Schell, J.A.; Deering, D.W. Monitoring vegetation systems in the Great Plains with ERTS. In Third Earth Resources Technology Satellite-1 Symposium; NASA Special Publication: Washington, DC, USA, 1974; pp. 309-317.

19. Barnes, E.M.; Clarke, T.R.; Richards, S.E.; Colaizzi, P.D.; Haberland, J.; Kostrzewski, M.; Waller, P.; Choi, C.; Riley, E.; Thompson, T. Coincident detection of crop water stress, nitrogen status and canopy density using ground-based multispectral data. In Proceedings of the International Conference on Precision Agriculture and Other Resource Management, Bloomington, IN, USA, 16-19 July 2000; pp. 16-19.

20. Jordan, C.F. Derivation of leaf-area index from quality of light on the forest floor. Ecology 1969, 50, 663-666. [CrossRef]

21. Qi, J.; Chehbouni, A.; Huete, A.; Kerr, Y.; Sorooshian, S. A modified soil adjusted vegetation index. Remote Sens. Environ. 1994, 48, 119-126. [CrossRef]

22. Chen, J.M. Evaluation of vegetation indices and a modified simple ratio for boreal applications. Can. J. Remote Sens. 1996, 22, 229-242. [CrossRef]

23. Reyniers, M.; Walvoort, D.J.J.; Baardemaaker, J.D. A linear model to predict with a multi-spectral radiometer the amount of nitrogen in winter wheat. Int. J. Remote Sens. 2006, 27, 4159-4179. [CrossRef]

24. Goel, N.S.; Qin, W. Influences of canopy architecture on relationships between various vegetation indices and LAI and FPAR. Remote Sens. Rev. 1994, 10, 309-347. [CrossRef]

25. Gong, P.; Pu, R.; Biging, G.S.; Larrieu, M.R. Estimation of forest leaf area index using vegetation indices derived from Hyperion hyperspectral data. IEEE Trans. Geosci. Remote 2003, 41, 1355-1362. [CrossRef]

26. Cao, Q.; Miao, Y.; Wang, H.; Huang, S.; Cheng, S.; Khosla, R.; Jiang, R. Non-destructive estimation of rice plant nitrogen status with Crop Circle multispectral active canopy sensor. Field Crop. Res. 2013, 154, 133-144. [CrossRef]

27. Jasper, J.; Reusch, S.; Link, A. Active sensing of the $\mathrm{N}$ status of wheat using optimized wave-length combination: Impact of seed rate, variety and growth stage. In Precision Agriculture'09; Henten, E.J.V., Goense, D., Lokhorst, C., Eds.; Wageningen Academic Publishers: Wageningen, The Netherlands, 2009; pp. 23-30.

28. Johnson, G.V.; Raun, W.R. Nitrogen response index as a guide to fertilizer management. J. Plant Nutr. 2003, 26, 249-262. [CrossRef]

29. Mullen, R.W.; Freeman, K.W.; Raun, W.R.; Johnson, G.V.; Stone, M.L.; Solie, J.B. Identifying an in-season response index and then potential to increase wheat yield with nitrogen. Agron. J. 2003, 95, 347-351. [CrossRef] 
30. Wang, X.; Miao, Y.; Dong, R.; Chen, Z.; Guan, Y.; Yue, X.; Fang, Z.; Mulla, D.J. Developing active canopy sensor-based precision nitrogen management strategies for maize in Northeast China. Sustainability 2019, 11, 706. [CrossRef]

31. Su, M.; Huang, S.; Zhao, G.; Zhao, Q.; Yao, Y.; Miao, Y. Current rice management practices of farmers in Heilongjiang land reclamation area and improvement strategies. North. Rice 2012, 42, 28-33, (In Chinese with English Abstract).

32. Li, S.; Ding, X.; Kuang, Q.; Ata-Ul-Karim, S.T.; Cheng, T.; Liu, X.; Tian, Y.; Zhu, Y.; Cao, W.; Cao, Q. Potential of UAV-based active sensing for monitoring rice leaf nitrogen status. Front. Plant Sci. 2018, 9, 1834. [CrossRef]

33. Aranguren, M.; Castellón, A.; Aizpurua, A. Crop sensor-based in-season nitrogen management of wheat with manure application. Remote Sens. 2019, 11, 1094. [CrossRef]

34. Cao, Q.; Miao, Y.; Li, F.; Gao, X.; Liu, B.; Lu, D.; Chen, X. Developing a new Crop Circle active canopy sensor-based precision nitrogen management strategy for winter wheat in North China Plain. Precis. Agric. 2017, 18, 2-18. [CrossRef]

35. Tubaña, B.S.; Arnall, D.B.; Walsh, O.; Chung, B.; Solie, J.B.; Girma, K.; Raun, W.R. Adjusting midseason nitrogen rate using a sensor-based optimization algorithm to increase use efficiency in corn. J. Plant Nutr. 2008, 31, 1393-1419. [CrossRef]

36. Macnack, N.; Khim, B.C.; Mullock, J.; Raun, W. In-season prediction of nitrogen use efficiency and grain protein in winter wheat (Triticum aestivum L.). Commun. Soil Sci. Plan. 2014, 45, 2480-2494. [CrossRef]

37. Purba, J.; Sharma, R.K.; Jat, M.L.; Thind, H.S.; Gupta, R.K.; Chaudhary, O.P.; Chandna, P.; Khurana, H.S.; Kumar, A.; Uppal, H.S.; et al. Site-specific fertilizer nitrogen management in irrigated transplanted rice (Oryza sativa) using an optical sensor. Precis. Agric. 2015, 16, 455-475.

38. Li, F.; Miao, Y.; Zhang, F.; Cui, Z.; Li, R.; Chen, X.; Zhang, H.; Schroder, J.; Raun, W.R.; Jia, L. In-season optical sensing improves nitrogen-use efficiency for winter wheat. Soil Sci. Soc. Am. J. 2009, 73, 1566-1574. [CrossRef]

39. Bonfil, D.J. Wheat phenomics in the field by RapidScan: NDVI vs. NDRE. Isr. J. Plant Sci. 2016, 1-14. [CrossRef]

40. Lu, J.; Miao, Y.; Shen, J.; Cao, Q.; Huang, S.; Wang, H.; Wu, H.; Hu, S.; Hu, X. Improving estimation of rice yield potential using active canopy sensor Crop Circle ACS 430 in Northeast China. In Precision Agriculture'15; Stafford, J.V., Ed.; Wageningen Academic Publishers: Wageningen, The Netherlands, 2015; pp. 102-115. [CrossRef]

41. Fan, M.; Shen, J.; Yuan, L.; Jiang, R.; Chen, X.; Davies, W.J.; Zhang, F. Improving crop productivity and resource use efficiency to ensure food security and environmental quality in China. J. Exp. Bot. 2011, 63, 13-24. [CrossRef]

42. Ju, C.; Buresh, R.J.; Wang, Z.; Zhang, H.; Liu, L.; Yang, J.; Zhang, J. Root and shoot traits for rice varieties with higher grain yield and higher nitrogen use efficiency at lower nitrogen rates application. Field Crop. Res. 2015, 175, 47-55. [CrossRef]

43. Ladha, J.K.; Pathak, H.; Krupnik, T.J.; Six, J.; Kessel, C.V. Efficiency of fertilizer nitrogen in cereal production: Retrospects and prospects. Adv. Agron. 2005, 87, 85-156.

44. Li, S.; Wang, Z.; Hu, T.; Gao, Y.; Stewart, B.A. Nitrogen in dryland soils of China and its management. Adv. Agron. 2009, 101, 123-181.

45. Wang, H.; Miao, Y.; Zhao, G.; Yao, Y.; Khosla, R. Evaluating different integrated precision rice management strategies in Northeast China. In Proceedings of the Second International Conference on Agro-Geoinformatics (Agro-Geoinformatics 2013), Fairfax, VA, USA, 12-16 August 2013; pp. 419-422. [CrossRef]

(C) 2020 by the authors. Licensee MDPI, Basel, Switzerland. This article is an open access article distributed under the terms and conditions of the Creative Commons Attribution (CC BY) license (http://creativecommons.org/licenses/by/4.0/). 